\title{
A global anthropogenic emission inventory of atmospheric pollutants from sector- and fuel-specific sources (1970-2017): an application of the Com- munity Emissions Data System (CEDS)
}

Erin E. McDuffie et al.

Correspondence to: Erin E. McDuffie (erin.mcduffie@wustl.edu)

The copyright of individual parts of the supplement might differ from the CC BY 4.0 License. 


\section{Section S1. CEDS Update Details: CEDSv2019-12-23 relative to CEDSv2016-07-26}

CEDSv2019-12-23 (Hoesly et al., 2019) was the first full public CEDS release (https://github.com/JGCRI/CEDS) and is used as the core system version in this work. An earlier version, CEDSv2016-07-26 was used to produce the CEDSHoesly inventory, as described in detail in Hoesly et al. (2018) and its supplement. Changes to the CEDS code between versions v2016-07-26 and v2019-12-23 are described in the CEDS System Release Notes on GitHub (https://github.com/JGCRI/CEDS/wiki/ Release-Notes). These updates include structural changes as well as improvements in the emissions data. The most significant improvements, which are also carried through to the $\mathrm{CEDS}_{\mathrm{GBD}-\mathrm{MAPS}}$ inventory include:

- Updated residential waste burning estimates

- $\quad$ Fixed an error in 1960s USA $\mathrm{SO}_{2}$ emissions and several other issues.

These updates are described in further detail in the following sections. A graphical summary of the differences between versions v2016-07-26 $\left(\right.$ CEDS $\left._{\text {Hoesly }}\right)$ and v2019-12-23 is available at the CEDS repository (https://github.com/JGCRI/CEDS/ at the link "Graphs of emission differences"). Additional updates are described in the CEDS System Release Notes (https://github.com/JGCRI/CEDS/wiki/Release-Notes) and the git log of the $\mathrm{CEDS}_{\mathrm{GBD}-\mathrm{MAPS}}$ system, available for download at https://github.com/emcduffie/CEDS/tree/CEDS_GBD-MAPS.

\section{S1.1 Residential waste burning}

Updates to emissions from residential open waste burning reduces emissions of all air pollutant species, particularly $\mathrm{BC}$ and $\mathrm{OC}$ emissions in lower income countries. The major change is a reduction in the assumed amount of uncollected waste that is burnt. The previous CEDS estimate was based on the 2010 value from Wiedinmyer et al. (2014) who assumed that $60 \%$ of uncollected solid waste was combusted. We conducted a literature survey, summarized below, to provide more insight into this value. We note that, for the purpose of emission estimation, the parameter we wish to know is the fraction of waste by weight that is combusted. This will be smaller than the fraction of waste that is disposed of through burning, since a significant portion of waste can be inert (e.g., ash, glass, and metals).

Reyna-Bensusan et al. (2018) examined waste disposal by surveying a "representative community" in Mexico about waste generation rates and disposal practices (Huejutla de Reyes Municipality). The Municipality has areas ranging from rural to urban and peri-urban in character. They found that in rural areas with limited access to municipal waste collection ( $69 \%$ had access only to a once-a-month service), $36 \%$ of household waste by weight was combusted. Commoner et al. (2000) additionally found in a survey in the Mexico state of Morelos that $14 \%$ of household waste was combusted in backyard burning, which corresponded to $52 \%$ of uncollected household waste, although only waste practices were surveyed, and waste generation rates were taken from national statistics. This is likely to overestimate the total amount of waste burnt since rural households generate half the waste per capita as compared to urban households (Reyna-Bensusan et al., 2018). 
Nagpure et al. (2015) examined waste disposal using a more direct field methodology in three neighborhoods in Delhi India. The neighborhood with the lowest socio-economic status, where "field observation showed very sparse waste management facilities" had the highest rate of waste burning of $~ 24 \%$ of the total generated.

For Indonesia, Meidiana and Gamse (2010) report on government statistics that imply that only $15 \%$ of uncollected waste was burnt in 2006, while 70\% was burnt in 2001. It is not clear if this difference is a true difference in burning rate, or different statistical methodologies.

Data is not necessary more available in higher income countries. In the United States residential waste has long been disposed by burning in barrels ("barrel burning"), particularly in rural areas. However, "The amount of refuse that is combusted annually in the United States in residential backyard burn barrels is largely unknown (US EPA, 2006)." This same report identified seven literature sources of survey data largely developed "to estimate the barrel-burning activity in a specific state, county, or region." The "prevalence of barrel burning within the rural population [was found] to range from 12 to 40\%". The EPA ultimately assumed that from 40\% (1995 and 1987) to $28 \%$ (2000) of the rural population burned household refuse, the decrease reflecting a larger number of jurisdictions banning refuse burning in 2000 as compared to earlier years. EPA further assumed that $63 \%$ of the household refuse (not including yard waste) was combusted. The confidence of these estimates is rated as low. Multiplying burning prevalence by the fraction of waste burnt results in overall waste burnt fractions of 25\% (1995 and 1987) and 18\% (2000) for rural populations.

Overall, the fraction of residential waste that is combusted is uncertain and is likely to vary spatially and over time. For the current estimate, informed by the literature discussed above, we assume that $30 \%$ of uncollected waste is bunt, which is half the value assumed by Wiedinmyer et al. (2014), with a correspondingly lower emissions level.

With one exception the per-capita waste generation rates from Wiedinmyer et al. (2014) have been retained. For India, however, we use the value from Sharma et al. (2019), which is twice the value in Wiedinmyer et al. (2014), leaving estimates from India largely unchanged.

\section{S1.2 Other Changes}

An error in US SO 2 emissions over the 1960s caused an incorrect step-increase in emissions in 1960 in CEDSv201607-26. This update will not be carried through to $\mathrm{CEDS}_{\mathrm{GBD}-\mathrm{MAPS}}$ as these emissions are reported from 1970 onward. An error that caused a spike in BC emissions in the Netherlands was also corrected and the consistency of Korea BC and $\mathrm{OC}$ emissions with the Korea national inventory was improved. These issues and their fixes are further described in the issues section of the CEDS GitHub repository. There are also small differences in the CEDSv2016-07-26 and CEDSv2019-12-23 emissions in the US after 2011, particularly $\mathrm{NH}_{3}$, due to scaling to more recent EPA Trends data. Note also that the monthly seasonality profile for the gridded industrial sector emissions was removed in CEDSv201912-23. While there is likely some seasonality in emissions in this sector, seasonality in the CEDSv2016-07-26 data was judged to be too large. 


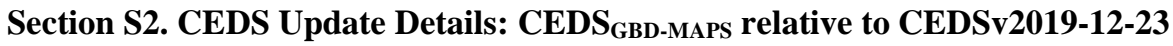

Section 2 in the Main Text describes updates to the CEDSv2019-12-23 code that are used to derive the new 1970 2017 CEDS $_{\text {GBD-MAPS }}$ inventory. Sections S2.1 - S2.5 below provide additional details regarding these updates. The $\mathrm{CEDS}_{\mathrm{GBD}-\mathrm{MAPS}}$ source code is available at: https://github.com/emcduffie/CEDS/tree/CEDS_GBD-MAPS.

\section{S2.1 Activity Data Updates - Additional Details}

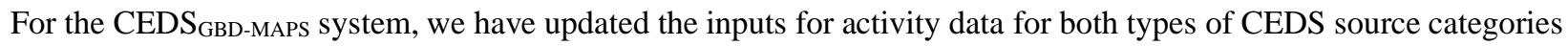
(combustion and process) in order to enable the extension of the $\mathrm{CEDS}_{\mathrm{GBD}-\mathrm{MAPS}}$ inventory out to the year 2017. We note that the distinction between CEDS combustion and process category sources is reflective of both the emission sector definition and CEDS methodology. For example, the 1A1bc_Other_transformation sector includes emissions from fuel combustion, but is treated as a process sector in CEDS due to the complexity of its processes, which include emissions from coal coke production, oil refining, and charcoal production (Hoesly et al., 2018). Other similar process sectors include emissions from the 5C_waste-incineration and 1B1_Fugitive-petr-and-gas sectors. Unlike CEDS combustion source categories, emissions from all process sectors are assigned to a single 'process' fuel-type, which may misallocate total emissions from biofuel, coal, and liquid oil and gas combustion to the process source category in the final fuel-specific $\mathrm{CEDS}_{\mathrm{GBD}-\mathrm{MAPS}}$ products, as discussed in Sect. 4.2.

\section{S2.1.1 Combustion Sources}

For $\mathrm{CEDS}_{\mathrm{GBD}-\mathrm{MAPS}}$ combustion category sources, activity data are primarily from energy consumption data, which have been updated to use the 2019 release of the World Energy Statistics from the International Energy Agency (IEA, 2019) for 40 OECD and 114 non-OECD countries and regions. For a small number of countries in Africa, Asia, and the Americas, data are only reported by the IEA at an aggregate region-level and are further disaggregated into their individual countries using historical $\mathrm{CO}_{2}$ emissions data, as described in Hoesly et al. (2018). Historical national-level $\mathrm{CO}_{2}$ emissions have been updated here to the most recent release from the Carbon Dioxide Information Analysis Center (CDIAC), which includes data from 1750 to 2014 (Boden et al., 2017). As IEA energy consumption data are provided at finer sectoral and fuel-type resolution than CEDS working sectors and fuels, CEDS Step 1 maps the IEA data to 52 working CEDS sectors and nine working fuel-types. Table S1 provides an example of the mapping between IEA fuels and CEDS working fuel types. Following the CEDSv2019-12-23 procedures, IEA data for residential biofuel consumption from the U.S. are replaced with renewable energy consumption data from the U.S. Energy Information Administration (EIA, 2019), which have been updated here to include the period from 1970 - 2017. In addition, $\mathrm{CEDS}_{\mathrm{GBD}-\mathrm{MAPS}}$ no longer applies corrections to the IEA data for coal consumption from China, which were previously used in the CEDSv2019-12-23 system. There is, however, a known issue in the updated IEA data from China that is listed in Sect. S4 below. As described in Hoesly et al. (2018), the CEDSv2019-12-23 system additionally used coal, oil, and gas consumption data from the BP Energy Statistics product (BP, 2015) to extend available IEA data (IEA, 2015) out to the year 2014. Complete IEA data for the year 2017 are available in this work (IEA, 2019), therefore BP energy statistics are no longer used to extend emission estimates, but have been updated $(\mathrm{BP}, 2019)$ here as they are also used to estimate emissions from fossil fuel flaring. 


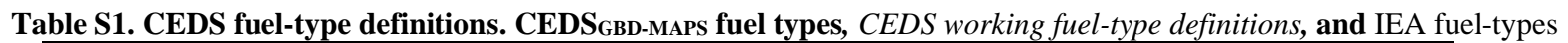
CEDS Fuels

\begin{tabular}{|c|c|}
\hline Coal & Liquid Fuel + Natural Gas \\
\hline Brown coal & \\
\hline Brown coal (if no detail) & Oil shale and oil sands \\
\hline Lignite & Crude/NGL/feedstocks \\
\hline Peat & Crude oil \\
\hline Peat products & Fuel oil \\
\hline Coal Coke & Bitumen \\
\hline Coke oven coke & Paraffin waxes \\
\hline Hard coal & Petroleum coke \\
\hline Hard coal (if no detail) & Other oil products \\
\hline Anthracite & Diesel Oil \\
\hline Coking coal & Gas/diesel oil excl. biofuels \\
\hline Other bituminous coal & Lubricants \\
\hline Sub-bituminous coal & Biodiesels \\
\hline Patent fuel & Light Oil \\
\hline Gas coke & Refinery stocks \\
\hline Coal tar & Additives/blending components \\
\hline $\mathrm{BKB}$ & Other hydrocarbons \\
\hline Biofuel & Ethane \\
\hline Biofuel & Liquefied petroleum gases (LPG) \\
\hline Industrial waste & Motor gasoline excl. biofuels \\
\hline Municipal waste (renewable) & Aviation gasoline \\
\hline Municipal waste (non-renewable) & Gasoline type jet fuel \\
\hline Primary solid biofuels & Kerosene type jet fuel excl. biofuels \\
\hline Non-specified primary biofuels/waste & Other kerosene \\
\hline Charcoal & Naptha \\
\hline Process & White spirit \& SBP \\
\hline \multirow[t]{12}{*}{ Process } & Biogasoline \\
\hline & Other liquid biofuels \\
\hline & Bio jet kerosene \\
\hline & Natural Gas \\
\hline & Natural gas liquids \\
\hline & Gas works gas \\
\hline & Coke oven gas \\
\hline & Blast furnace gas \\
\hline & Other recovered gases \\
\hline & Natural gas \\
\hline & Refinery gas \\
\hline & Biogases \\
\hline
\end{tabular}




\section{S2.1.2 Process Sources}

For $\mathrm{CEDS}_{\mathrm{GBD}-\mathrm{MAPS}}$ process category sources, activity drivers are primarily from the UN World Population and World Urbanization Prospects, which are updated here to extend to 2017 (UN, 2019, 2018). These data are used as activity drivers for all CEDS process sources except for 5C_waste-incineration, 1B2_Fugitive-pert-and-gas, and 1B2d_Fugitive-other-energy. As described in Hoesly et al. (2018), pulp and paper consumption data (FAOSTAT, 2015) are used for default emission estimates of waste incineration (held constant here after 2014), while the latter two sectors now use a composite product that is derived from updated 2019 IEA energy statistics. World Bank data were not updated in this work (last year 2014) relative to CEDSv2019-12-23 since these data are only used to supplement population data for Kosovo. Table S2 summarizes the activity driver dataset updates that are used in

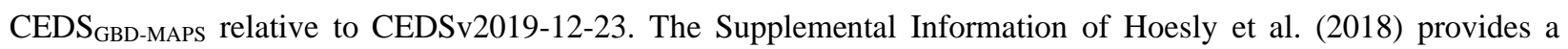
complete list of all additional CEDS input datasets, which have not been updated in this work.

Table S2. Comparison of activity driver datasets that are updated between CEDSv2019-12-23 and CEDSGBD-MAPS Systems. For a complete list of CEDS activity drivers, see Hoesly et al. (2018).

\begin{tabular}{lll}
\hline $\begin{array}{l}\text { CEDS Emission } \\
\text { Source Category }\end{array}$ & Hoesly et al. (2018) & CEDSGBD-MAPS \\
\hline Fuel combustion & (IEA, 2015) & (IEA, 2019) \\
& (BP, 2015) & (BP, 2019) (flaring estimates only) \\
& EIA, 2(The World Bank, 2016;UN, 2014, & (EIA, 2019) (biofuel from US) \\
& $\begin{array}{l}\text { 2015;Wiedinmyer et al., 2014)015 (biofuel from US) } \\
\text { (Boden et al., 2016) }\end{array}$ & \\
& (BN, 2014, 2015) & (UN, 2019, 2018) \\
& (The World Bank, 2016) & (The World Bank, 2016) \\
& (FAOSTAT, 2015) & (FAOSTAT, 2015) \\
\hline
\end{tabular}

\section{S2.2. Emission Factors \& Inventory Input Updates - Additional Details}

\section{S2.2.1 Combustion Sources}

The datasets used to calculate default emission factors $(\mathrm{EF})$ for combustion sources in the CEDS $\mathrm{GBD}$-MAPS system are largely unchanged relative to those in CEDSv2019-12-23 (see Table 2 in Hoesly et al. (2018) for a complete list). For reactive gases, combustion EFs are primarily estimated using information from the GAINS model (as released for the Energy Modeling Forum 30 (EMF30) project (Klimont et al., 2017;Stohl et al., 2015)), SPEW for BC and OC (Bond et al., 2007), and the U.S. 2011 NEI for $\mathrm{NH}_{3}$. As described in Hoesly et al. (2018), EF calculations take into account historical changes in emission abatement strategies, while some EFs for $\mathrm{SO}_{2}$ are also calculated explicitly using fuel sulfur content, ash retention, and country-specific percent controls (NEI, 2013). EF and emission calculations do not include information about the vertical distribution of emissions. For countries with missing contemporary sectoral or fuel-type information, EFs are extended forward to 2017 using trends from GAINS projections. The minimum allowable EFs for road transportation have also been extended to 2017, which ensures the use of realistic EFs from this sector in recent years for countries with missing data.

\section{S2.2.2 Process Sources}


For non-combustion sectors, EFs in $\mathrm{CEDS}_{\mathrm{GBD}-\mathrm{MAPS}}$ Step 1 are estimated using existing emission inventories and calculated activity drivers, as described previously in Sect. 2.1. These emission estimates are primarily from the global EDGAR inventory, which has been updated in this work to use a more recent release of EDGAR (v4.3.2; EC-JRC, 2018; Crippa et al., 2018). For emissions of waste combustion, all versions of the CEDS system use country-specific EFs for 2010 from Wiedinmyer et al. (2014), along with estimates of the total mass. As described in Sect. S1.1 above, relative to CEDSv2016-07-26, assumptions for the fraction of waste burnt have been updated in both CEDSv2019-

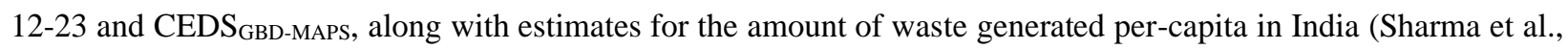
2019). Additional details on these updates can be found in the core CEDS system release notes (https://github.com/JGCRI/CEDS/wiki/Release-Notes). Similar to combustion sources, missing EFs are also extended forward and backwards in time to produce a complete time series for 1970 - 2017. Table 2 in Hoesly et al. (2018) provides a complete list of all input datasets used to estimate default process source emissions. Other than those described here, all remaining datasets are unchanged in this work relative to CEDSv2019-12-23. Despite uncertainties in contemporary EFs and default emission estimates for both source categories, many of these values are later scaled to match contemporary regional and national-level inventories (see Sect. 2.2).

\section{S2.3 Default CEDS Emissions Scaling Procedure Updates - Additional Details}

\section{S2.3.1 Scaling Mapping Files \& Misc. Details}

The first step of the scaling procedure is to aggregate emissions from common sectors and fuel-types into "scaling sectors" and "scaling fuel" groups (when fuel-specific emissions are available) for each scaling inventory. This is necessary as there are often differences in the availability and definitions of emission from source sectors and fueltypes between CEDS and the scaling inventories. Total default CEDS emissions within these aggregate groups are then scaled to the corresponding emissions in each scaling inventory, using the scaling factors calculated from Eq. (2) in the main text. All mapping files can be found at: https://github.com/emcduffie/CEDS/tree/CEDS_GBDMAPS/input/mappings/scaling, with specific examples described below.

The first column in each mapping file provides the sectoral names from the scaling inventory. When emissions are reported as a function of fuel type, the second column lists the fuel-types reported for each emission sector in the scaling inventory. When applicable, column three defines the aggregate scaling fuel groups. Column four defines the aggregate scaling sector groups. Columns five and six list the CEDS working sectors and working fuels that correspond to these aggregate scaling groups. Table S3 provides an example scaling mapping file for the DICEAfrica scaling inventory. Table S3 shows that the DICE-Africa inventory reports combined emissions from gas (petrol) and diesel use in cars and motorcycles. The CEDS system does not differentiate between different types of on-road sources and therefore, DICE-Africa emissions from both cars and motorcycles are mapped to the common 'road_transport' scaling sector, which corresponds to the CEDS 1A3b_Road sector. Similarly, the DICE-Africa inventory does not distinguish between emissions from gas and diesel fuel, therefore total CEDS road emissions from light_oil and diesel_oil combustion in the road sector are scaled to the total DICE-Africa emissions reported for cars and motorcycles. Example scaling factors for select years and countries in Africa, as a function of scaling sector are provided in Table S4. Data are included for illustrative purposes only. Following original CEDS protocols, scaling 
factors are limited to values between 0.01 and 100 , with select inventories and sectors expanded to a range of 0.001 and 1000, as described below in Section S2.3.2. As discussed in Hoesly et al. (2018), particularly small or large scaling factors may result for multiple reasons, including default CEDS estimates that are drastically different than regional emissions or imprecise mapping between CEDS and regional emission sectors.

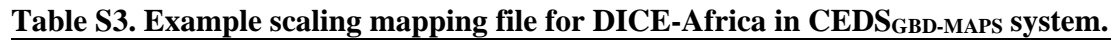

\begin{tabular}{|c|c|c|c|c|c|}
\hline DICE-Africa sector & DICE-Africa fuel & Scaling Fuel & Scaling Sector & CEDS Sector & CEDS Fuel \\
\hline \multirow[t]{2}{*}{ cars } & gas_diesel & gas_diesel & road_transport & 1A3b_Road & light_oil \\
\hline & & gas_diesel & road_transport & 1A3b_Road & diesel_oil \\
\hline motorcycles & gas diesel & gas diesel & road transport & & \\
\hline charcoal-use & biomass & biomass & residential & 1A4b_Residential & biomass \\
\hline household-crop-residue-use & biomass & biomass & residential & & \\
\hline household-fuelwood-use & biomass & biomass & residential & & \\
\hline kerosene-use & light_oil & light_oil & residential & 1A4b_Residential & light_oil \\
\hline other-fuelwood-use ${ }^{a}$ & biomass & $\mathrm{n} / \mathrm{a}$ & $\mathrm{n} / \mathrm{a}$ & $\mathrm{n} / \mathrm{a}$ & $\mathrm{n} / \mathrm{a}$ \\
\hline adhoc-oil-refining $^{\mathrm{a}}$ & process & $\mathrm{n} / \mathrm{a}$ & $\mathrm{n} / \mathrm{a}$ & $\mathrm{n} / \mathrm{a}$ & $\mathrm{n} / \mathrm{a}$ \\
\hline generator-use $^{\mathrm{a}}$ & gas_diesel & $\mathrm{n} / \mathrm{a}$ & $\mathrm{n} / \mathrm{a}$ & $\mathrm{n} / \mathrm{a}$ & $\mathrm{n} / \mathrm{a}$ \\
\hline charcoal-production $^{\mathrm{a}}$ & biomass & $\mathrm{n} / \mathrm{a}$ & $\mathrm{n} / \mathrm{a}$ & $\mathrm{n} / \mathrm{a}$ & $\mathrm{n} / \mathrm{a}$ \\
\hline gas-flares $^{\mathrm{a}}$ & process & $\mathrm{n} / \mathrm{a}$ & $\mathrm{n} / \mathrm{a}$ & $\mathrm{n} / \mathrm{a}$ & $\mathrm{n} / \mathrm{a}$ \\
\hline
\end{tabular}

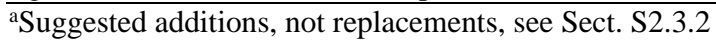

Table S4. Example BC scaling factors for select DICE-Africa countries and years.

\begin{tabular}{|l|l|l|l|l|l|l|l|l|l|l|l|l|}
\hline $\begin{array}{l}\text { Country } \\
\text { (ISO) }\end{array}$ & $\begin{array}{l}\text { Scaling } \\
\text { Sector }\end{array}$ & $\begin{array}{l}\text { Scaling } \\
\text { Fuel }\end{array}$ & $\mathbf{2 0 0 6}$ & $\mathbf{2 0 0 7}$ & $\mathbf{2 0 0 8}$ & $\mathbf{2 0 0 9}$ & $\mathbf{2 0 1 0}$ & $\mathbf{2 0 1 1}$ & $\mathbf{2 0 1 2}$ & $\mathbf{2 0 1 3}$ & $\mathbf{2 0 1 4}$ & $\mathbf{2 0 1 5}$ \\
\hline ago & residential & biomass & 0.332 & 0.338 & 0.344 & 0.350 & 0.355 & 0.361 & 0.367 & 0.373 & 0.373 & 0.373 \\
\hline ago & residential & light oil & 0.340 & 0.311 & 0.282 & 0.252 & 0.223 & 0.194 & 0.165 & 0.136 & 0.136 & 0.136 \\
\hline ago & $\begin{array}{l}\text { road_ } \\
\text { transport }\end{array}$ & $\begin{array}{l}\text { gas_ } \\
\text { diesel }\end{array}$ & 0.307 & 0.293 & 0.278 & 0.264 & 0.250 & 0.235 & 0.221 & 0.207 & 0.207 & 0.207 \\
\hline nam & residential & biomass & 0.297 & 0.320 & 0.342 & 0.364 & 0.386 & 0.409 & 0.431 & 0.453 & 0.453 & 0.453 \\
\hline nam & residential & light oil & 44.71 & 44.72 & 44.72 & 44.72 & 44.73 & 44.73 & 44.73 & 44.74 & 44.74 & 44.74 \\
\hline nam & $\begin{array}{l}\text { road_ } \\
\text { transport }\end{array}$ & $\begin{array}{l}\text { gas_ } \\
\text { diesel }\end{array}$ & 0.274 & 0.260 & 0.247 & 0.234 & 0.220 & 0.207 & 0.194 & 0.180 & 0.180 & 0.180 \\
\hline
\end{tabular}

Relative to CEDS v2019-12-23, minor adjustments have been made to other inventory scaling mapping files in order to better reflect the overlap between $\mathrm{CEDS}_{\mathrm{GBD}-\mathrm{MAPS}}$ working sectors and the updated scaling inventories. One example is the adjustment of scaling factors for agricultural $\mathrm{NO}_{\mathrm{x}}$ emissions for the U.S. NEI and Canadian APEI inventories. In these national inventories, $\mathrm{NO}_{\mathrm{x}}$ emissions from soils are not reported (report $\mathrm{NH}_{3}$ emissions only). In CEDSv2019-12-23, $\mathrm{NO}_{\mathrm{x}}$ emissions from the sum of all agricultural working sectors $(3 \mathrm{~B}+3 \mathrm{D}+3 \mathrm{E}+3 \mathrm{I}$; including soil emissions) are scaled to the total agricultural $\mathrm{NO}_{\mathrm{x}}$ emissions reported in these scaling inventories, resulting in scaled CEDS agricultural $\mathrm{NO}_{\mathrm{x}}$ emissions that are erroneously low. In this work, CEDS $\mathrm{GBD-MAPS}$ 3D_Soil-emissions from the US and Canada are no longer scaled to these inventories and default emission estimates are used for this working sector. These updated scaling mapping files can be found at: https://github.com/emcduffie/CEDS/tree/CEDS_GBDMAPS/input/mappings/scaling.

After the scaling procedure, $\mathrm{CEDS}_{\mathrm{GBD}-\mathrm{MAPS}}$ emissions are then disaggregated back into the original $52 \mathrm{CEDS}$ working sectors and 9 working fuel-types (Table 2, combustion source only) using the initial fractional contributions from each sector and fuel-type. This method allows CEDS to maintain detailed fuel and sectoral information while simultaneously scaling total country-level emissions to authoritative inventories. This process, however, often results

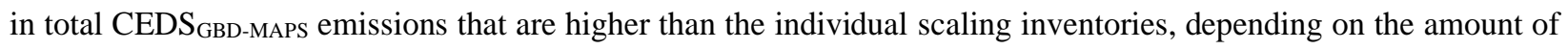




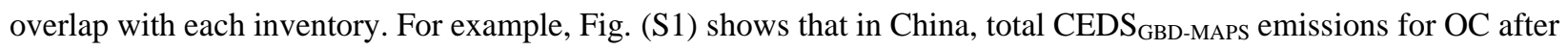
2010 are larger than those in the national scaling inventory, reported by Zheng et al. (2018). This difference is largely

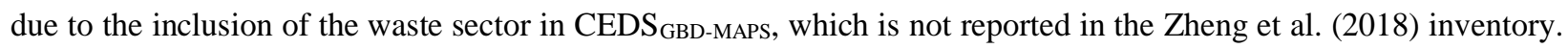
In contrast, other inventories report emissions from sources that are not included in CEDS, such as open burning on agricultural fields or road dust emissions. In these cases, these sectors are not included in the CEDS scaling procedure and are not included in the final $\mathrm{CEDS}_{\mathrm{GBD}-\mathrm{MAPS}}$ inventory. In addition, sectors such as domestic shipping are not scaled and are always set to default CEDS estimates due to large uncertainties and differences in the definitions of these sectors in individual scaling inventories. To illustrate the outcome of the scaling procedure, implied emission factors for the top 15 emitting countries are additionally shown in Figure S2 for the select fuel-types and sectors that dominantly contribute to global emission of each compound. Various anomalies in the implied EFs can arise from multiple sources of uncertainty, including the underlying activity data or application of scaling factors outside the available scaling inventory years, as is the case with the on-road CO emission factor for China in 1999. These uncertainties are discussed further in Section 4.2 in the main text.

\section{Regional Comparison (China): OC}

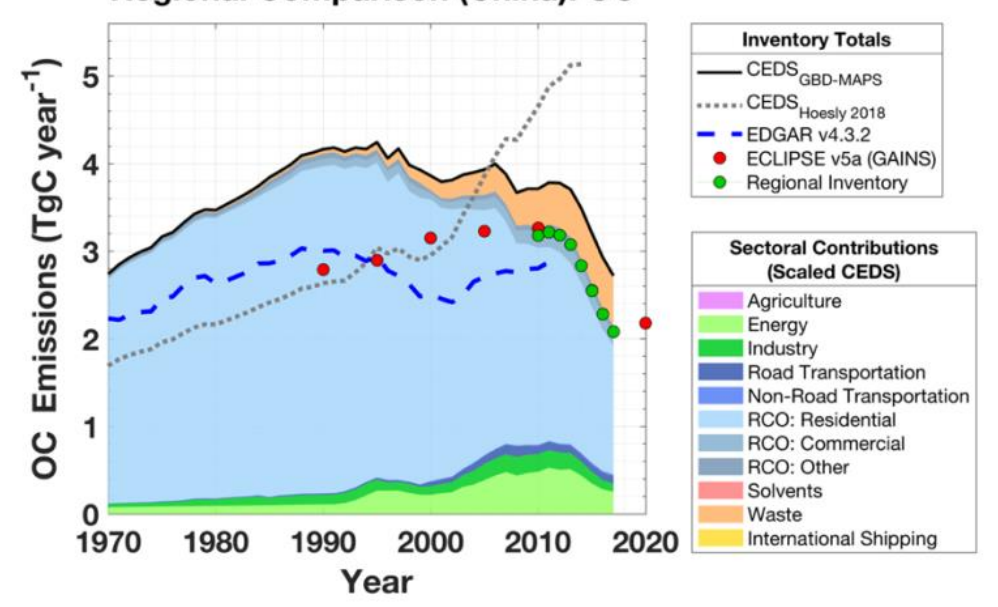

Figure S1. Inventory comparison of annual OC emissions from China. Black line) total CEDSGBD-MAPS emissions, colored by sectoral contributions, dashed gray line) CEDS Hoesly emissions, dashed blue line) EDGAR v4.3.2 emissions, red dots) ECLIPSE v5a (GAINS) inventory with 2015 and 2020 projections, green dots) scaling inventory from Zheng et al. (2018). This comparison does not include contributions from agricultural waste burning, shipping, or aviation emissions. 


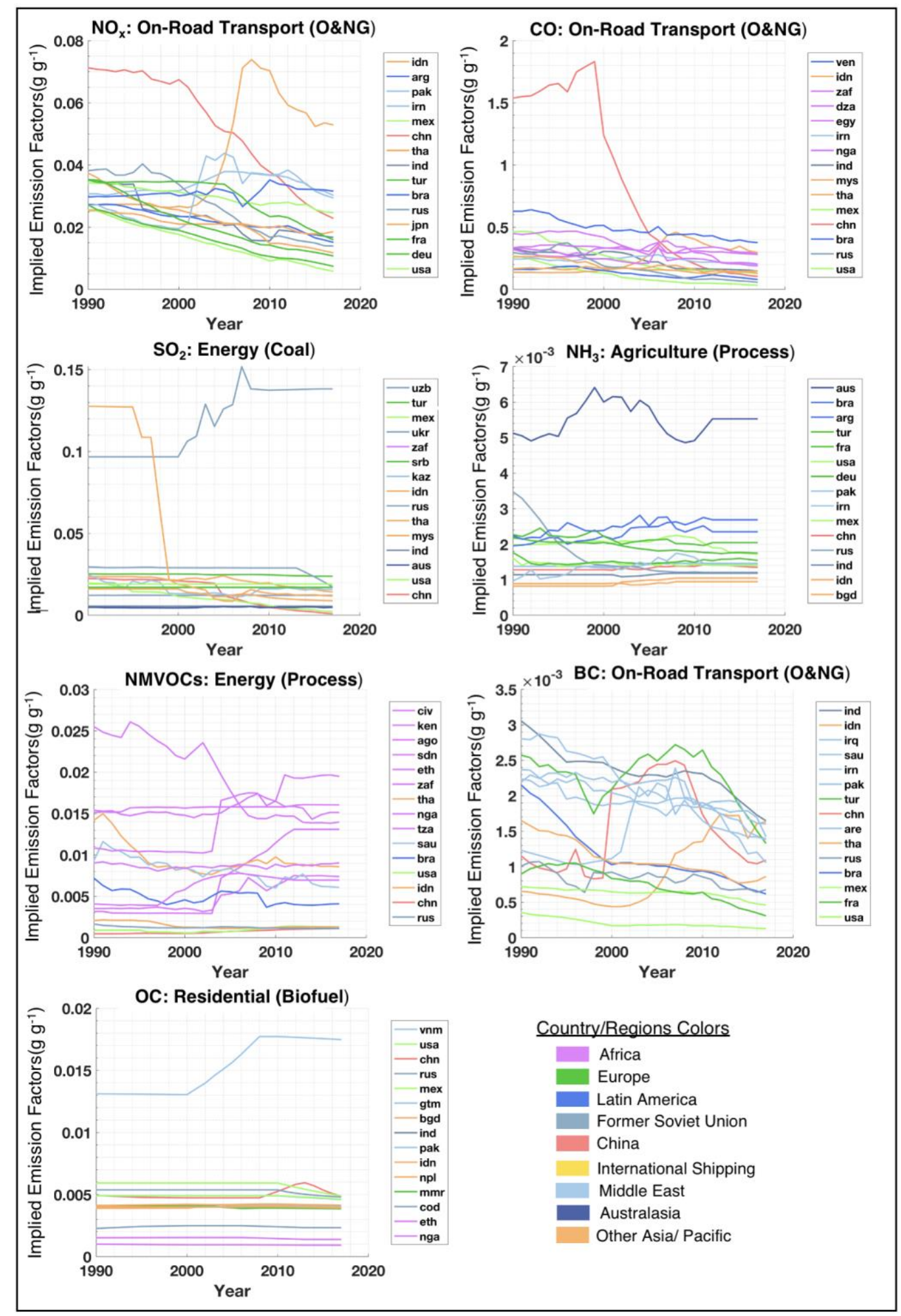

Figure S2. Time-series of implied (post-scaling) emission factors for select fuel and sector combinations that dominantly contribute to global emissions of each compounds. NOx, CO, and BC: oil \& natural gas combustion in the on-road transport sector, $\mathrm{SO}_{2}$ : coal combustion in the energy sector, $\mathrm{NH}_{3}$ : agricultural emissions, NMVOCs: process-level energy sources, and OC: residential biofuel combustion. Time series are shown for the top 15 emitting countries, listed by their ISO codes to the right of each panel. Time series are colored by the region of each country. 


\section{S2.3.2 Africa Emissions Scaling}

As discussed in the main text, new scaling inventories are included in this work for emissions from India and Africa. For African countries, default CEDS $_{\text {GBD-MAPS }}$ emissions for residential and road sectors are scaled to the respective values in the DICE-Africa inventory (Marais and Wiedinmyer, 2016) for 2006 and 2013, as a function of diesel, light oil (Table S1), and biofuel use. For years between 2006 and 2013, scaling factors (SFs) from Eq. (2) in the main text are linearly interpolated within the CEDS system. These SFs are held constant before 2006 and after 2013. DICEAfrica OC emissions from cars are additionally scaled by 0.14 prior to the CEDS scaling procedure in order to correct for a previous error in the DICE-Africa OC EFs (http://wiki.seas.harvard.edu/geos-chem/index.php/DICEAfrica anthropogenic emissions inventory\#Scale DICE-Africa_emissions to address errors in inventory).

Upper and lower bounds of scaling factor are additionally relaxed here to limits of 1000 and 0.001 (100 and 0.01 in

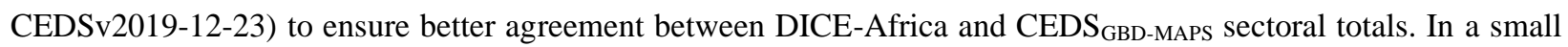
number of instances, calculated scaling factors are outside this range, which may reflect differences in sectoral definitions between the two inventories or real uncertainties in the magnitude of sectoral-level emissions in Africa.

As also noted in the main text, DICE-Africa emission estimates from gas flares across Africa and ad-hoc oil refining in the Niger Delta are not included in the $\mathrm{CEDS}_{\mathrm{GBD}-\mathrm{MAPS}}$ scaling procedure (Table S2). Total default $\mathrm{CEDS}_{\mathrm{GBD}}$ MAPS emissions in Africa for each compound in 2013 from the 1B2_fugitive_petr_gas (gas flaring) sector are almost always larger than the respective DICE-Africa gas-flaring emissions, suggesting that emissions from this source sector may be accurately represented in default $\mathrm{CEDS}_{\mathrm{GBD}-\mathrm{MAPS}}$ estimates. However, in the event that gas-flaring emissions from the DICE-Africa inventory are not accounted for in the $\mathrm{CEDS}_{\mathrm{GBD}-M A P S}$ default emissions, the CEDS $\mathrm{GBD}_{\text {MAPS }}$ 1B2_fugitive_petr_gas emissions across Africa may be underestimated by up to $28 \%$ (or up to $<0.01 \mathrm{Tg}$ ) for each compound in 2013 (Table S3).

In addition, DICE-Africa emissions from petrol/diesel use in residential generators, as well as fuelwood use for charcoal production and other commercial activities are not included in the CEDS $_{\text {GBD-MAPS }}$ scaling procedure. These sectors are not explicitly represented by the CEDS $_{\text {GBD-MAPS }}$ working sectors and are only expected to be represented in the $\mathrm{CEDS}_{\mathrm{GBD}-\mathrm{MAPS}}$ default estimates to the extent that these sources are included in the IEA energy consumption data. Emissions from charcoal production will be allocated to the 1A1bc_Other-Transformation sector, while commercial fuelwood use would be allocated to the 1A4a_Commercial-institutional sector. In the event that these sources are not included in default CEDS $_{\text {GBD-MAPs }}$ emissions, the emissions from biofuel use in the CEDS other transformation and commercial sectors in 2013 may be underestimated by up to 100\% (or up to $6 \mathrm{Tg}$ ) for each compound (Table S5). Similarly, residential generator use may be allocated to the 1A4b_Residential (RCO-R) and/or 1A4c_Agriculture-forestry-fishing (RCO-Other) sectors. In the event that generators are not accounted for in default estimates, CEDS emissions from light oil/diesel use in the residential sectors may be underestimated by up to $84 \%$ (or up to $0.25 \mathrm{Tg}$ ) for each compound (Table S5). While these maximum possible under-predictions represent large fractions of emissions from individual fuels and sectors, the sum of these potential missing emissions correspond to maximum under-predictions in total $2013 \mathrm{CEDS}_{\mathrm{GBD}-\mathrm{MAPS}}$ emissions in Africa of less than $11 \%$ (or $<10.5 \mathrm{Tg}$ ) for each compound (Table S3). Possible under-predictions of $<11 \%$ are within typical uncertainties of bottom-up emission 
inventories (Sect. 4.2.3). Table S5, however, does indicate that some emissions from commercial and residential

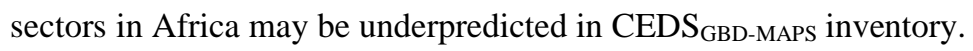

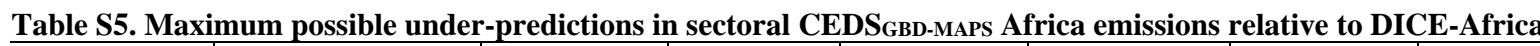

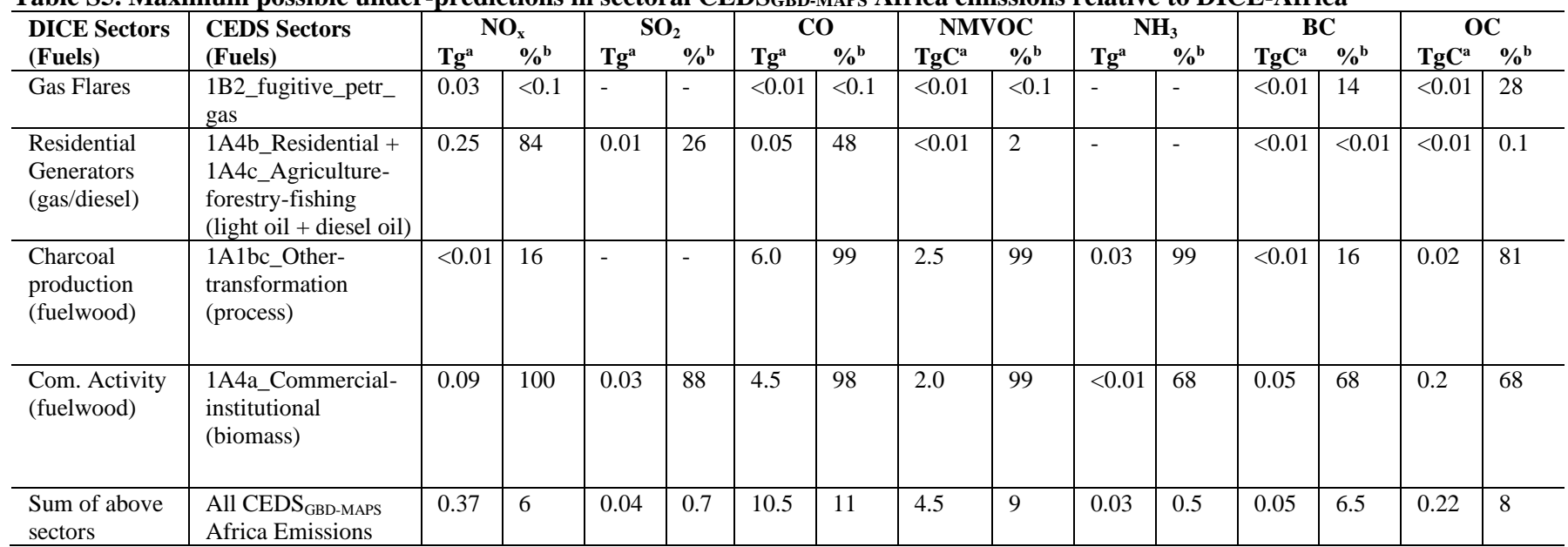

${ }^{a}$ Sum DICE-Africa 2013 emissions from each country within the given sector

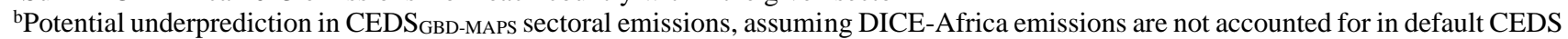
estimates (i.e., 100* (CEDS ${ }_{\mathrm{GBD}-\mathrm{MAPS}}$ Em. + DICE-Africa Em.)/ CEDS ${ }_{\mathrm{GBD}-\mathrm{MAPS}}$ Em.)

As discussed in the main text, Fig. 3 compares the scaled CEDS $_{\text {GBD-MAPS }}$ emissions of all compounds in

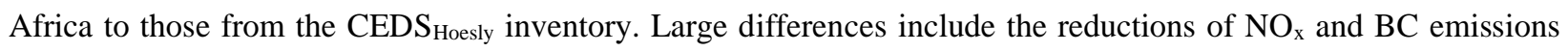
from the on-road transport sector in $\mathrm{CEDS}_{\mathrm{GBD}-\mathrm{MAPS}}$ relative to the $\mathrm{CEDS}_{\text {Hoesly }}$ inventory. As discussed in Sect. 2.2, these reductions are largely driven by a difference in EFs used for emissions from diesel vehicles. For the on-road transport sector, the DICE-Africa inventory uses activity data from the UN energy database for total petrol/diesel use in the transport sector, which is then divided into usage for motorcycles and vehicles as described in Marais and Wiedinmyer (2016). Vehicle activity data are not split further, and a single EF is applied to total vehicle activity data to calculate DICE-Africa emissions from all on-road cars. This DICE-Africa EFs for cars are consistent with the default CEDS EFs for on-road gasoline emissions and will be more representative of light vehicles than larger diesel trucks, which have default EFs in CEDS roughly twice as large.

\section{S2.3.2 India Emissions Scaling}

We also scale emissions from India to a new 2015 emissions inventory described in Venkataraman et al. (2018) (SMoG-India). Similar scaling sector and fuel definitions are defined as described above. As described in the main text, emissions for $\mathrm{NO}_{x}, \mathrm{SO}_{2}, \mathrm{CO}, \mathrm{NMVOCs}, \mathrm{OC}$, and $\mathrm{BC}$ are available for 17 sectors and nine fuel types. Scaling mapping files can be found at: https://github.com/emcduffie/CEDS/tree/CEDS_GBD-MAPS/input/mappings/scaling. Scaling factors were calculated for the year 2015 and applied forward and back to the entire 1970 - 2017 timeseries. Due to uncertainties in the sectoral mapping and applicability of 2015 scaling factors over the entire time period, we note the potential misallocation of the SMoG-India 'Informal Industry' sector to the CEDS $\mathrm{GBD}-\mathrm{MAPS}$ 1A2c_ind-CombFood-tobacco sector (rather than the $1 \mathrm{~A} 2 \mathrm{~g}$-Comb-Ind-other sector). This misallocation results in $\mathrm{CEDS}_{\mathrm{GBD}-\mathrm{MAPS}} \mathrm{NO}_{\mathrm{x}}$ emissions in India possibly overpredicted by up to $\sim 1$ Tg between 1987-2014 (see also Sect. S4). While sectoral 
misallocations impact the magnitude of sub-sector emissions, total $\mathrm{CEDS}_{\mathrm{GBD}-\mathrm{MAPS}}$ industry emissions in 2015 are equivalent to total industry emissions (information + light + heavy industry) from the SMoG-India inventory.

In addition, there are cases where default CEDS emissions for a specific sector/fuel-type combination equal 0 , resulting in emissions of 0 after the scaling process. To avoid missing emissions in these instances, CEDS working fuel types are aggregated into "scaling fuels" (total coal, total liquid fuel, natural gas, and process emissions) in a similar manor to the scaling sectors (as described above in Sect. S2.3), and are later re-allocated to the CEDS working fuel types according to distributions prior to scaling. While this process may result in a slightly different fuel distribution at the most detailed level, final $\mathrm{CEDS}_{\mathrm{GBD}-\mathrm{MAPS}}$ emissions (both gridded and country-level products) are aggregated into contributions from total coal, biofuel, oil and gas, and process emissions.

\section{S2.4 Default BC and OC Emission Scaling Procedure Updates - Additional Details}

Relative to CEDS v2019-12-23, BC and OC emissions are now scaled to available regional- and national-level inventories. $\mathrm{CEDS}_{\mathrm{GBD}-\mathrm{MAPS}}$ emissions for $\mathrm{OC}$ and $\mathrm{BC}$ from countries within each scaling inventory are shown in Fig.

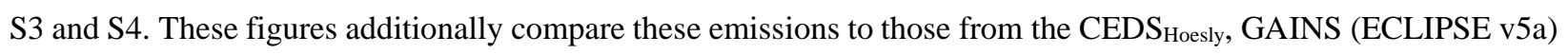
(Klimont et al., 2017), EDGAR v4.3.2 (Crippa et al., 2018), and scaling inventories. As described above and in the main text, regional inventories and final $\mathrm{CEDS}_{\mathrm{GBD}-\mathrm{MAPS}}$ emissions may not agree depending on the level of overlap between the sectoral emissions included in each scaled inventory. For example, the national emissions from China (Zheng et al., 2018) are lower than the $\mathrm{CEDS}_{\mathrm{GBD}-\mathrm{MAPS}}$ estimates due to waste emissions that are not included in the national-inventory.

It should also be noted that emissions from the metal and chemical industrial sectors in Japan are underestimated in both $\mathrm{CEDS}_{\text {Hoesly }}$ and $\mathrm{CEDS}_{\mathrm{GBD}-\mathrm{MAPS}}$ relative to the country level inventory (preliminary update from Kurokawa et al., 2013). Default CEDS emissions for these sectors are estimated to be zero in CEDS Step 1 and are therefore not scaled to the available inventory emissions. This underprediction is largest for years prior to 1995 (see Fig. S4) and is reduced in recent years due to a decreasing fractional contribution of these sectors to total OC and $\mathrm{BC}$ emissions in the Kurokawa et al., 2013 inventory (40\% to 28\% for OC, $2 \%$ to 1.6\%. for BC between 1990 and 2010). In addition, $\mathrm{CEDS}_{\mathrm{GBD}-\mathrm{MAPS}}$ emissions are not scaled to EMEP emissions (EMEP, 2019) prior to 2000 due to changes in inventory reporting (Fig. S3). 


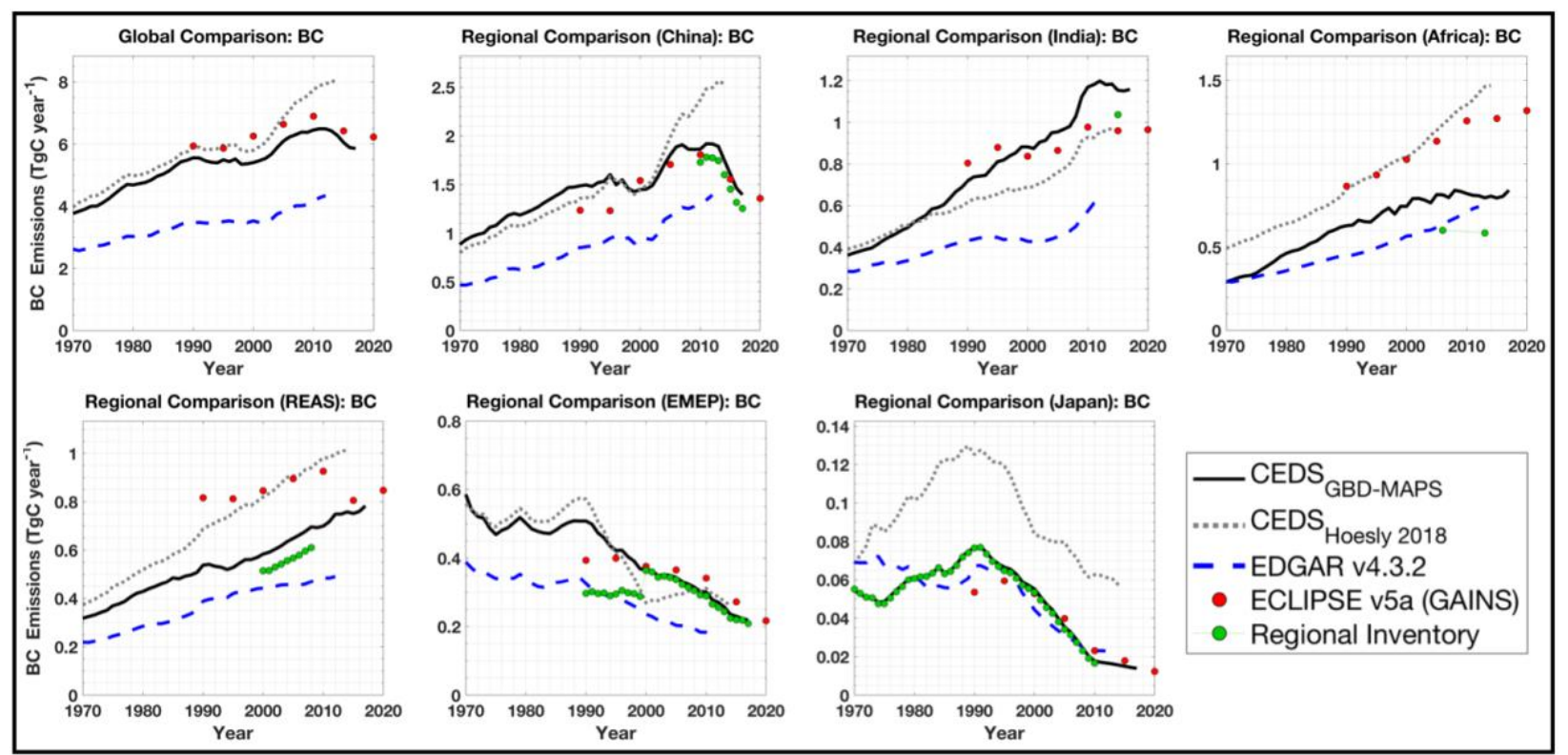

Figure S3. Time series of BC emissions from CEDS dashed line), and ECLIPSE v5a baseline current legislation (CLE) inventory from the GAINS model (red dots). Each panel shows total annual emissions from each designated country/region. GAINS values for 2015 and 2020 are emission projections. Global inventories show reported emissions from all sectors excluding open burning, shipping, and aviation. Respective regional inventories are shown by green dots/lines and include all reported emissions that are also included in regional CEDS ${ }_{\text {GBD-MAPS }}$ emissions (e.g., do not include open burning, road dust, shipping, aviation, etc). Note: in the regional comparisons, CEDS GBD-MAPs, $_{\text {, CEDS }}$ Hesly, and EDGAR v4.3.2 emissions also include inland navigation, while GAINS v5a CLE do not include any shipping emissions. In the global comparison, all available shipping emissions (inland navigation and international shipping) are included in each inventory. REAS and EMEP member countries listed in Table S6.

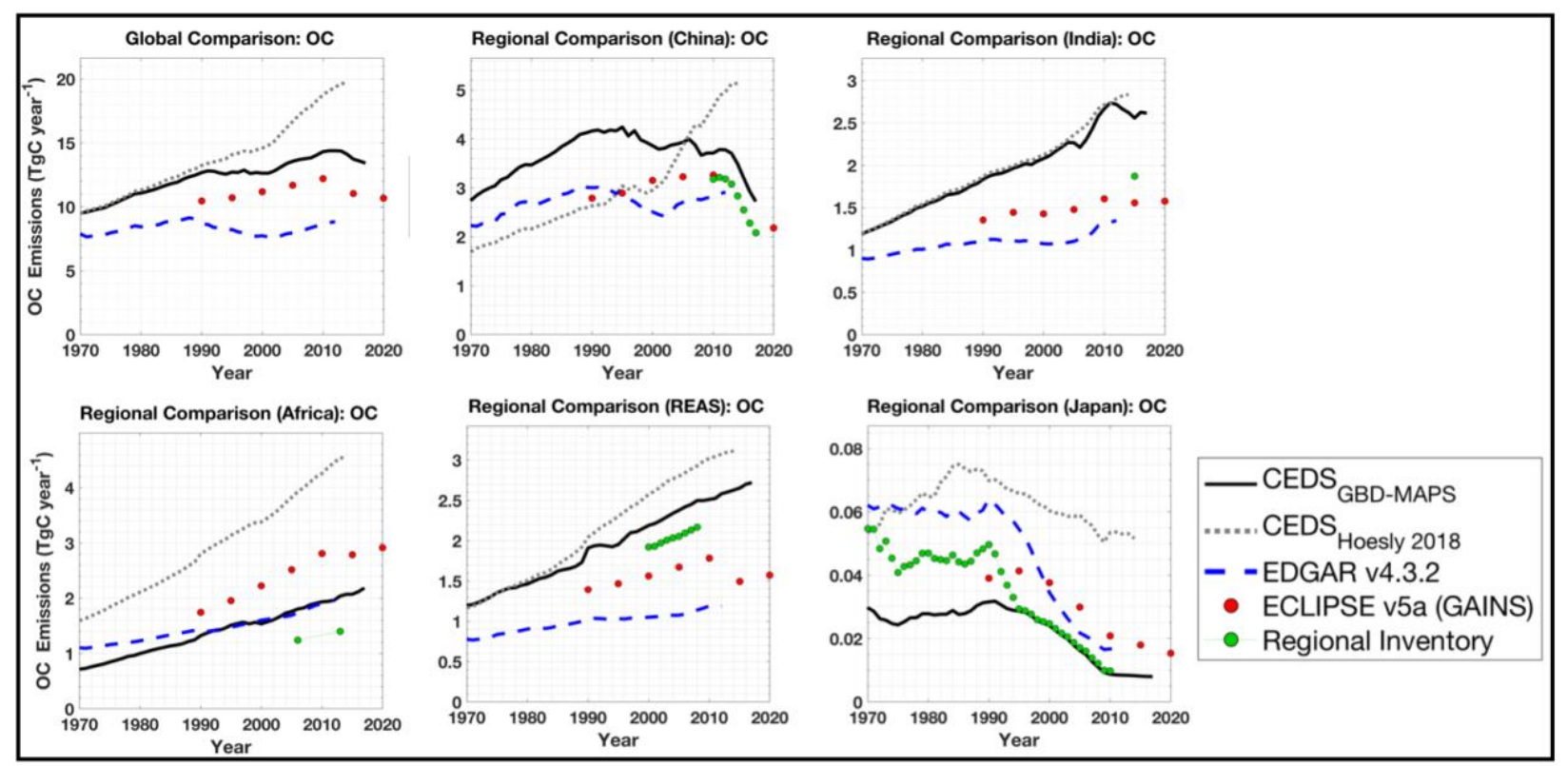

Figure S4. Same as Fig. S3, but for OC emissions. 
Table S6. Countries included in REAS and EMEP regions

\begin{tabular}{|l|llll|}
\hline REAS & Afghanistan & Bhutan & Brunei Darussalam & Cambodia \\
& Bangladesh & Maldives & DPR Korea & Kyrgyzstan \\
& Indonesia & Myanmar & Kazakhstan & Singapolia \\
& Laos & Sri Lanka & Nepal & Thailand \\
& Malaysia & Turkmenistan & Pakistan & Uzbekistan \\
& Tajikistan & Vietnam & Philippines & Czech Republic \\
& Taiwan & & & Estonia \\
& Albania & Armenia & Belgium & Germany \\
& Belarus & Austria & Cyprus & Kyngary \\
& Bulgaria & Croatia & France & Latvia \\
& Denmark & Finland & Italy & Netherlands \\
& Georgia & Greece & Malta & Romania \\
& Iceland & Ireland & Montenegro & Switzerland \\
& Luxembourg & Macedonia & Portugal & Slovenia \\
& Norway & Poland & Spain & \\
& Sweden & Slovakia & & \\
& United Kingdom & & & \\
\hline
\end{tabular}

\section{S2.5 Spatial Gridding \& Aggregation Updates - Additional Details}

Relative to CEDSv2019-12-23, CEDS emissions prior to gridding are now aggregated into 17 intermediate sectors as a function of four fuel categories: total coal (hard coal + brown coal + coal coke), solid biofuel, the sum of liquid fuel (heavy oil + light oil + diesel oil) and natural gas, and all remaining 'process' emissions.

CEDS Step 5 then spatially allocates total country-level emission estimates on to a $0.5^{\circ} \times 0.5^{\circ}$ global grid to facilitate their use in earth system models. The procedure for spatially allocating CEDS total country-level emissions

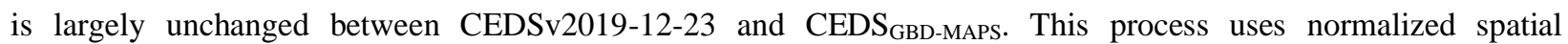
distribution proxies that are compound- and sector-specific. In CEDSv2019-12-23, proxy distribution data are primarily from gridded EDGAR emissions (v4.2 and v4.3) (EC-JRC/PBL, 2012, 2016) and HYDE population (Klein Goldewijk et al., 2011) (primarily for historical extension prior to 1970 and waste emissions). In CEDSv2019-12-23, gridding proxies are then held constant after 2008 or 2010 (ROAD transportation only). For the CEDS GBD-MAPS inventory, we have updated the compound- and sector-specific normalized spatial proxies for 1970 - 2012 to use the most recent release of the EDGAR inventory (v4.3.2) (Table S7). Spatial proxies are then held constant for all years after 2012. These updates extend many of the latest spatial proxies from 2008 to 2012 but may still introduce uncertainty in the gridded CEDS $_{\mathrm{GBD}-\mathrm{MAPS}}$ products between 2013 and 2017 for sectoral emissions that have experienced large changes in their normalized spatial distributions within large countries (Sect. 4.2.5). The same sector-specific gridding proxy is also applied to emissions from each fuel group within each sector. This process may introduce additional uncertainties into the gridded $\mathrm{CEDS}_{\mathrm{GBD}-\mathrm{MAPS}}$ products as discussed in Sect. 4.2. These uncertainties do not impact the final country-level $\mathrm{CEDS}_{\mathrm{GBD}-\mathrm{MAPS}}$ products because they are not gridded.

As further described in Hoesly et al. (2018), sectors that do not have congruent emissions between CEDS and EDGAR v4.3.2 inventories use population data from HYDE (Klein Goldewijk et al., 2011) and Gridded Population of the World (GPW) (Doxsey-Whitfield et al., 2015) products as backup spatial proxies. Supplemental Table S7 provides a complete list of gridding proxies as a function of sector. All sectors that do not use EDGAR data use the same spatial proxies as in CEDSv2019-12-23. For example, emissions from the waste sector are gridded using 
yearly estimates of population, which have not been updated relative to CEDSv2019-12-23 and are therefore held constant after the year 2015 .

Table S7. Gridding proxies used for spatial allocation, listed by sector.

\begin{tabular}{|c|c|c|c|}
\hline CEDS final sectors & $\begin{array}{l}\text { CEDS intermediate gridding } \\
\text { sectors }\end{array}$ & Spatial Proxy & Years $^{\mathbf{b}}$ \\
\hline Agriculture (AGR) & Agriculture & EDGAR v4.3.2 AGR & $1970-2012$ \\
\hline \multirow[t]{2}{*}{ International Shipping (SHP) } & International Shipping & ECLIPSE and additional data ${ }^{c}$ & $\begin{array}{l}1990,1995,2000, \\
2005,2010,2015\end{array}$ \\
\hline & $\begin{array}{l}\text { International Shipping (tanker } \\
\text { loading) }\end{array}$ & ECLIPSE and additional data ${ }^{c}$ & 1996 \\
\hline On-Road Transportation (ROAD) & On-Road Transportation & EDGARv4.3.2 ROAD & 2010 \\
\hline $\begin{array}{l}\text { Non-Road Transportation } \\
\text { (NRTR) }\end{array}$ & Non-Road Transportation & EDGAR v4.3.2 NRTR & $1970-2012$ \\
\hline $\begin{array}{l}\text { Residential, Commercial, Other - } \\
\text { Residential (RCOR) }\end{array}$ & $\begin{array}{l}\text { Residential, Commercial, Other - } \\
\text { Residential }\end{array}$ & EDGAR v4.3.2 RCO & $1970-2012$ \\
\hline $\begin{array}{l}\text { Residential, Commercial, Other - } \\
\text { Commercial (RCOC) }\end{array}$ & $\begin{array}{l}\text { Residential, Commercial, Other - } \\
\text { Commercial }\end{array}$ & EDGAR v4.3.2 RCO & $1970-2012$ \\
\hline $\begin{array}{l}\text { Residential, Commercial, Other - } \\
\text { Other (RCOO) }\end{array}$ & $\begin{array}{l}\text { Residential, Commercial, Other - } \\
\text { Other }\end{array}$ & EDGAR v4.3.2 RCO & $1970-2012$ \\
\hline \multirow[t]{4}{*}{ Energy (ENE) } & Oil and gas fugitive/flaring & ECLIPSE FLR $^{\mathrm{c}}$ & $1970-2015$ \\
\hline & Electricity and heat production & EDGAR v4.3.2 ELEC & $1970-2012$ \\
\hline & Fuel production and transformation & EDGAR v4.3.2 ETRN & $1970-2012$ \\
\hline & Fossil Fuel Fires & EDGAR v4.3.2 FFFI & $1970-2012$ \\
\hline Waste (WST) & Waste & $\begin{array}{l}\text { HYDE population, GPW v4 } \\
\text { (modified rural population) }^{\mathrm{c}}\end{array}$ & $1970-2015$ \\
\hline \multirow[t]{2}{*}{ Industry (IND) } & Industrial Combustion & EDGAR v4.3.2 INDC & $1970-2012$ \\
\hline & Industrial process and product use & EDGAR v4.3.2 INPU & $1970-2012$ \\
\hline $\begin{array}{l}\text { Solvent production and } \\
\text { application (SLV) }\end{array}$ & $\begin{array}{l}\text { Solvent production and application } \\
\text { (SLV) }\end{array}$ & EDGAR v4.3.2 SLV & $1970-2012$ \\
\hline
\end{tabular}

${ }^{\mathrm{a} A l l}$ species and sectors use population as a backup proxy.

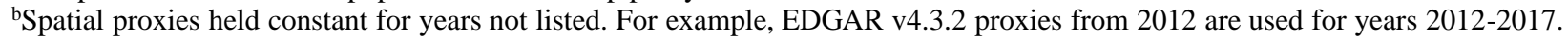
All sectors use population as a backup proxy (2016-2017 use 2015 population).

${ }^{\mathrm{c}}$ Not updated relative $\mathrm{CEDS}_{\text {Hoesly }}$ inventory.

After the gridding procedure, the 17 intermediate sectors are then aggregated into 11 final sectors, by effectively splitting the original CEDSv2019-12-23 emissions from the TRA sector into 'On-Road' and 'NonRoad/Other' contributions and splitting the original RCO sector into individual contributions from the Residential, Commercial, and Other sectors. Table 2 contains a complete breakdown of the definitions of CEDS working, intermediate gridding, and final sectors. Figure S5 illustrates the level of detail available in this new CEDS ${ }_{\text {GBD-MAPS }}$ inventory by illustrating global BC emissions in 2017 from 1) all source sectors, 2) the residential sector only, 3) residential biofuel-use only, and 4) residential coal-use only. 


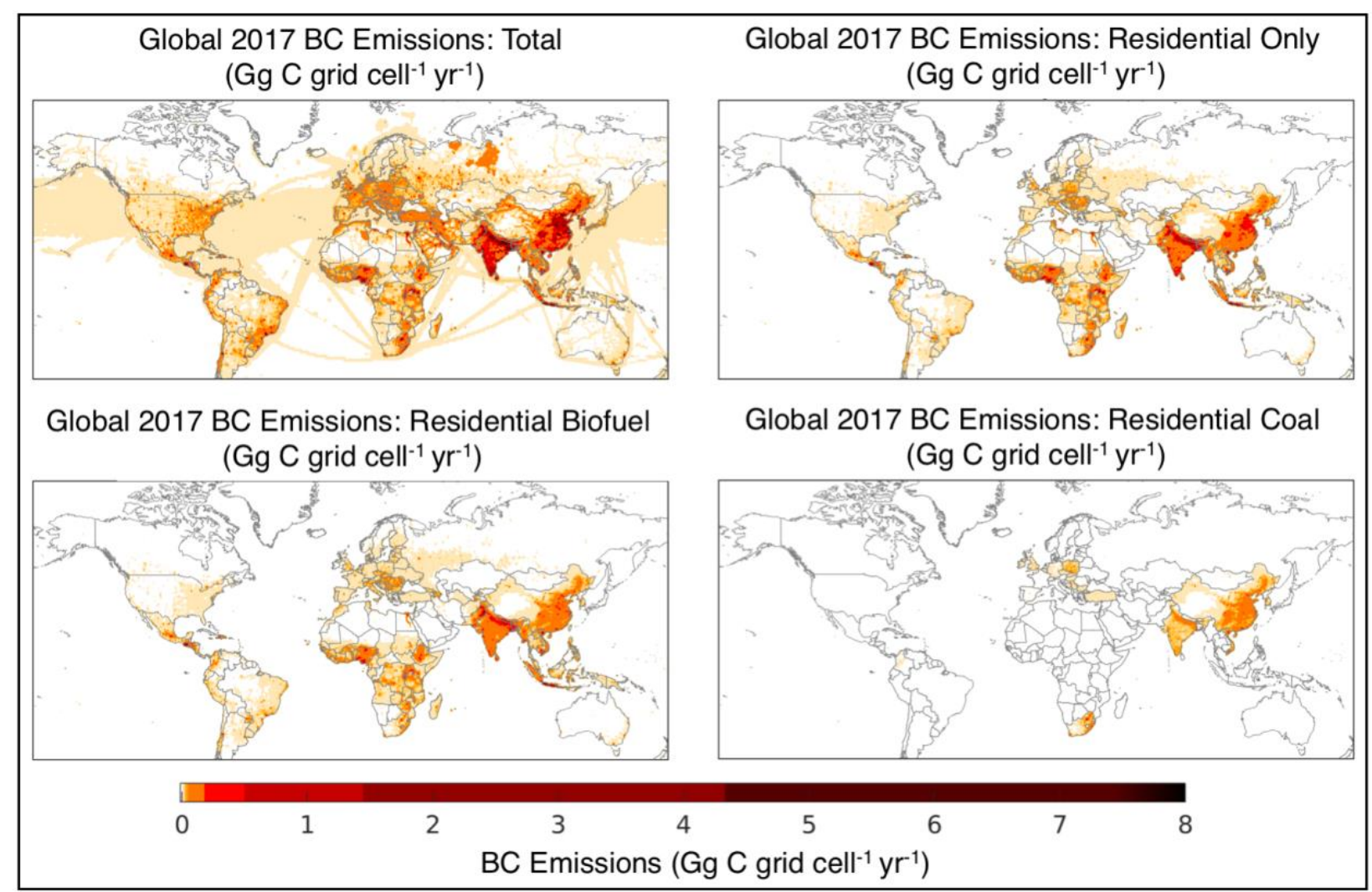

Figure S5. Map of global BC emissions for 2017 from (top left) all sectors, (top right) residential emissions only, (bottom left) residential biofuel only, and (bottom right) residential coal only. 
Section S3. Supplemental Results

Table S8. Fractional sectoral and fuel-type contributions to 2017 global emissions of each compound. Sectoral contributions in bold sum to $100 \%$ for each compound (i.e., AGR + ENE +... SHP =100\%). Fractional contributions of fuel-types within each sector sum to $100 \%$ for each compound (i.e., ENE coal + ENE biofuel + ENE Oil+Gas + ENE Process =100\%).

\begin{tabular}{|c|c|c|c|c|c|c|c|c|}
\hline Sector & Fuel-Type & NO $_{\mathrm{x}}$ & $\mathrm{CO}$ & $\mathrm{SO}_{2}$ & $\mathrm{NH}_{3}$ & NMVOC & BC & $\mathrm{OC}$ \\
\hline AGR & Total & $5 \%$ & - & - & $75 \%$ & - & - & - \\
\hline AGR & Coal & - & - & - & - & - & - & - \\
\hline AGR & Biofuel & - & - & - & - & - & - & - \\
\hline AGR & $\mathrm{Oil}+\mathrm{Gas}$ & - & - & - & - & - & - & - \\
\hline AGR & Process & 100 & - & - & 100 & - & - & - \\
\hline ENE & Total & $22 \%$ & $11 \%$ & $42 \%$ & $2 \%$ & $36 \%$ & $10 \%$ & $8 \%$ \\
\hline$\overline{\mathrm{ENE}}$ & Coal & 46 & 10 & 63 & 4 & $<1$ & 3 & 7 \\
\hline ENE & Biofuel & 3 & 2 & $<1$ & 3 & $<1$ & 15 & 53 \\
\hline ENE & $\mathrm{Oil}+\mathrm{Gas}$ & 35 & 8 & 18 & 6 & $<1$ & 2 & $<1$ \\
\hline ENE & Process & 16 & 80 & 19 & 87 & 99 & 80 & 40 \\
\hline IND & Total & $15 \%$ & $14 \%$ & $36 \%$ & $2 \%$ & $6 \%$ & $12 \%$ & $10 \%$ \\
\hline IND & Coal & 49 & 36 & 38 & 5 & 25 & 47 & 17 \\
\hline IND & Biofuel & 10 & 11 & 1 & 39 & 25 & 24 & 78 \\
\hline IND & Oil + Gas & 36 & 5 & 25 & 11 & 9 & 29 & 5 \\
\hline IND & Process & 5 & 48 & 36 & 45 & 41 & - & - \\
\hline ROAD & Total & $23 \%$ & $32 \%$ & $2 \%$ & $1 \%$ & $17 \%$ & $20 \%$ & $7 \%$ \\
\hline ROAD & Coal & - & - & - & - & - & - & - \\
\hline ROAD & Biofuel & - & - & - & - & - & - & - \\
\hline ROAD & $\mathrm{Oil}+\mathrm{Gas}$ & 100 & 100 & 100 & 100 & 100 & 100 & 100 \\
\hline ROAD & Process & - & - & - & - & - & - & - \\
\hline NRTR & Total & $6 \%$ & $1 \%$ & $1 \%$ & $<1 \%$ & $1 \%$ & $1 \%$ & $<1 \%$ \\
\hline NRTR & Coal & $<1$ & $<1$ & $<1$ & $<1$ & $<1$ & $<1$ & $<1$ \\
\hline NRTR & Biofuel & - & - & - & - & - & - & - \\
\hline NRTR & $\mathrm{Oil}+\mathrm{Gas}$ & 100 & 100 & 100 & 100 & 100 & 100 & 100 \\
\hline NRTR & Process & $<1$ & $<1$ & $<1$ & $<1$ & $<1$ & $<1$ & $<1$ \\
\hline RCOR & Total & $3 \%$ & $35 \%$ & $4 \%$ & $6 \%$ & $18 \%$ & $38 \%$ & $54 \%$ \\
\hline RCOR & Coal & 9 & 13 & 68 & $<1$ & 2 & 13 & 8 \\
\hline RCOR & Biofuel & 57 & 86 & 22 & 96 & 97 & 70 & 92 \\
\hline RCOR & $\mathrm{Oil}+\mathrm{Gas}$ & 34 & 1 & 10 & 3 & 1 & 17 & $<1$ \\
\hline RCOR & Process & - & - & - & - & - & - & - \\
\hline RCOC & Total & $1 \%$ & $<1 \%$ & $2 \%$ & $<1 \%$ & $<1 \%$ & $5 \%$ & $4 \%$ \\
\hline $\mathrm{RCOC}$ & Coal & - & 47 & 68 & 23 & 16 & 45 & 38 \\
\hline $\mathrm{RCOC}$ & Biofuel & - & 12 & 1 & 28 & 29 & 28 & 54 \\
\hline $\mathrm{RCOC}$ & $\mathrm{Oil}+\mathrm{Gas}$ & 100 & 41 & 31 & 49 & 55 & 27 & 8 \\
\hline RCOC & Process & - & - & - & - & - & - & - \\
\hline RCOO & Total & $3 \%$ & $3 \%$ & $1 \%$ & $<1 \%$ & $1 \%$ & $6 \%$ & $2 \%$ \\
\hline $\mathrm{RCOO}$ & Coal & 2 & 10 & 36 & 12 & 4 & 13 & 22 \\
\hline $\mathrm{RCOO}$ & Biofuel & 1 & 21 & 1 & 11 & 23 & 10 & 48 \\
\hline $\mathrm{RCOO}$ & $\mathrm{Oil}+\mathrm{Gas}$ & 97 & 69 & 63 & 77 & 73 & 77 & 30 \\
\hline $\mathrm{RCOO}$ & Process & - & - & - & - & - & - & - \\
\hline SLV & Total & - & - & - & $<1 \%$ & $17 \%$ & - & - \\
\hline SLV & Coal & - & - & - & - & - & - & - \\
\hline SLV & Biofuel & - & - & - & - & - & - & - \\
\hline SLV & $\mathrm{Oil}+\mathrm{Gas}$ & - & - & - & - & - & - & - \\
\hline SLV & Process & - & - & - & 100 & 100 & - & - \\
\hline WST & Total & $2 \%$ & $3 \%$ & $<1 \%$ & $14 \%$ & $2 \%$ & $5 \%$ & $13 \%$ \\
\hline WST & Coal & - & - & - & - & - & - & - \\
\hline WST & Biofuel & - & - & - & - & - & - & - \\
\hline WST & Oil + Gas & - & - & - & - & - & - & - \\
\hline WST & Process & 100 & 100 & 100 & 100 & 100 & 100 & 100 \\
\hline SHP & Total & $20 \%$ & $<1 \%$ & $12 \%$ & $<1 \%$ & $2 \%$ & $3 \%$ & $1 \%$ \\
\hline SHP & Coal & - & - & - & - & - & - & - \\
\hline SHP & Biofuel & - & - & - & - & - & - & - \\
\hline SHP & $\mathrm{Oil}+\mathrm{Gas}$ & 100 & 100 & 100 & 100 & 27 & 100 & 100 \\
\hline SHP & Process & - & - & - & - & 73 & - & - \\
\hline
\end{tabular}


Table S9. Region/Country definitions for main text Fig. 8 and supplemental Fig. S7-S20 (grouped by geographical location)

\begin{tabular}{|c|c|c|c|c|}
\hline Region/Country & Member Countries & & & \\
\hline Africa & $\begin{array}{l}\text { Algeria } \\
\text { Burkina Faso } \\
\text { Cameroon } \\
\text { Cape Verde } \\
\text { Eritrea } \\
\text { Guinea } \\
\text { Kenya } \\
\text { Madagascar } \\
\text { Mauritius } \\
\text { Niger } \\
\text { Sao Tome and Principe } \\
\text { Somalia } \\
\text { Tunisia } \\
\text { Zimbabwe } \\
\end{array}$ & $\begin{array}{l}\text { Angola } \\
\text { Botswana } \\
\text { Chad } \\
\text { DR Congo } \\
\text { Ethiopia } \\
\text { Gambia } \\
\text { Liberia } \\
\text { Malawi } \\
\text { Morocco } \\
\text { Nigeria } \\
\text { Senegal } \\
\text { South Africa } \\
\text { Swaziland } \\
\text { Uganda } \\
\end{array}$ & $\begin{array}{l}\text { Burundi } \\
\text { Central African Republic } \\
\text { Congo } \\
\text { Djibouti } \\
\text { Gabon } \\
\text { Guinea-Bissau } \\
\text { Libya } \\
\text { Mali } \\
\text { Mozambique } \\
\text { Reunion } \\
\text { Seychelles } \\
\text { South Sudan } \\
\text { Tanzania } \\
\text { Western Sahara } \\
\end{array}$ & $\begin{array}{l}\text { Benin } \\
\text { Cote d'Iviore } \\
\text { Comoros } \\
\text { Egypt } \\
\text { Ghana } \\
\text { Equatorial Guinea } \\
\text { Lesotho } \\
\text { Mauritania } \\
\text { Namibia } \\
\text { Rwanda } \\
\text { Sierra Leone } \\
\text { Sudan } \\
\text { Togo } \\
\text { Zambia } \\
\end{array}$ \\
\hline China & China & & & \\
\hline Europe & $\begin{array}{l}\text { Albania } \\
\text { Bulgaria } \\
\text { Denmark } \\
\text { Gibraltar } \\
\text { Iceland } \\
\text { Luxembourg } \\
\text { Netherlands } \\
\text { Romania } \\
\text { Spain } \\
\text { United Kingdom }\end{array}$ & $\begin{array}{l}\text { Austria } \\
\text { Croatia } \\
\text { Finland } \\
\text { Greece } \\
\text { Ireland } \\
\text { Macedonia } \\
\text { Norway } \\
\text { Serbia and Montenegro } \\
\text { Sweden }\end{array}$ & $\begin{array}{l}\text { Belgium } \\
\text { Cyprus } \\
\text { France } \\
\text { Greenland } \\
\text { Italy } \\
\text { Malta } \\
\text { Poland } \\
\text { Slovakia } \\
\text { Switzerland }\end{array}$ & $\begin{array}{l}\text { Bosnia } \\
\text { Czech Republic } \\
\text { Germany } \\
\text { Hungary } \\
\text { Liechtenstein } \\
\text { Montenegro } \\
\text { Portugal } \\
\text { Slovenia } \\
\text { Turkey }\end{array}$ \\
\hline $\begin{array}{l}\text { Former Soviet } \\
\text { Union }\end{array}$ & $\begin{array}{l}\text { Armenia } \\
\text { Georgia } \\
\text { Lithuania } \\
\text { Russia } \\
\end{array}$ & $\begin{array}{l}\text { Azerbaijan } \\
\text { Kazakhstan } \\
\text { Moldova } \\
\text { Ukraine } \\
\end{array}$ & $\begin{array}{l}\text { Belarus } \\
\text { Kyrgyzstan } \\
\text { Tajikistan } \\
\text { Uzbekistan } \\
\end{array}$ & $\begin{array}{l}\text { Estonia } \\
\text { Latvia } \\
\text { Turkmenistan }\end{array}$ \\
\hline India & India & & & \\
\hline $\begin{array}{l}\text { Latin } \\
\text { America/Oceania }\end{array}$ & $\begin{array}{l}\text { Antigua and Barbuda } \\
\text { Barbados } \\
\text { Brazil } \\
\text { Colombia } \\
\text { Dominica } \\
\text { Faeroe Islands } \\
\text { Guadeloupe } \\
\text { Honduras } \\
\text { Mexico } \\
\text { Panama } \\
\text { Saint Lucia } \\
\text { Trinidad and Tobago } \\
\text { Venezuela }\end{array}$ & $\begin{array}{l}\text { Argentina } \\
\text { Belize } \\
\text { British Virgin Islands } \\
\text { Costa Rica } \\
\text { Dominican Republic } \\
\text { Falkland Islands } \\
\text { Guatemala } \\
\text { Haiti } \\
\text { Montserrat } \\
\text { Paraguay } \\
\text { St Pierre and Miquelon } \\
\text { Turks and Caicos Islands }\end{array}$ & $\begin{array}{l}\text { Aruba } \\
\text { Bermuda } \\
\text { Cayman Islands } \\
\text { Cuba } \\
\text { Ecuador } \\
\text { French Guiana } \\
\text { Jamaica } \\
\text { Netherland Antilles } \\
\text { Peru } \\
\text { Sint Maarten } \\
\text { St Vincent and } \\
\text { Grenadines } \\
\text { US Virgin Islands }\end{array}$ & $\begin{array}{l}\text { Bahamas } \\
\text { Bolivia } \\
\text { Chile } \\
\text { Curacao } \\
\text { El Salvador } \\
\text { Grenada } \\
\text { Guyana } \\
\text { Martinique } \\
\text { Nicaragua } \\
\text { Saint Kitts and Nevis } \\
\text { Suriname } \\
\text { Uruguay }\end{array}$ \\
\hline North America & United States & Canada & Puerto Rico & \\
\hline $\begin{array}{l}\text { Other Asia/ } \\
\text { Pacific }\end{array}$ & $\begin{array}{l}\text { American Samoa } \\
\text { Cambodia } \\
\text { Fiji } \\
\text { Indonesia } \\
\text { Macao } \\
\text { Mongolia } \\
\text { Niue } \\
\text { Republic of Korea } \\
\text { Sri Lanka } \\
\text { Tokelau } \\
\text { Wallis and Futuna Islands }\end{array}$ & $\begin{array}{l}\text { Bangladesh } \\
\text { Cook Islands } \\
\text { French Polynesia } \\
\text { Japan } \\
\text { Malaysia } \\
\text { Myanmar } \\
\text { Palau } \\
\text { Samoa } \\
\text { Taiwan } \\
\text { Tongo }\end{array}$ & $\begin{array}{l}\text { Bhutan } \\
\text { DPR Korea } \\
\text { Guam } \\
\text { Kiribati } \\
\text { Maldives } \\
\text { Nepal } \\
\text { Papua New Guinea } \\
\text { Singapore } \\
\text { Thailand } \\
\text { Vanuatu }\end{array}$ & $\begin{array}{l}\text { Brunei Darussalam } \\
\text { FS of Micronesia } \\
\text { Hong Kong } \\
\text { Laos } \\
\text { Marshall Islands } \\
\text { New Caledonia } \\
\text { Philippines } \\
\text { Soloman Islands } \\
\text { Timor-Leste } \\
\text { Vietnam }\end{array}$ \\
\hline Australasia & Australia & New Zealand & & \\
\hline Middle East & $\begin{array}{l}\text { Afghanistan } \\
\text { Israel } \\
\text { Pakistan } \\
\text { Saudi Arabia }\end{array}$ & $\begin{array}{l}\text { Bahrain } \\
\text { Jordan } \\
\text { Palestine } \\
\text { Syria }\end{array}$ & $\begin{array}{l}\text { Iraq } \\
\text { Kuwait } \\
\text { Oman } \\
\text { United Arab Emirates }\end{array}$ & $\begin{array}{l}\text { Islamic Republic of Iran } \\
\text { Lebanon } \\
\text { Qatar } \\
\text { Yemen }\end{array}$ \\
\hline
\end{tabular}


To supplement the results presented in Sect. 3, Fig. S6 provides time series of the contributions of each source sector to global emissions, for each compound. Figures S7-S12 additionally show time series of sectoral emissions of each compound in dominant source regions, including North America, Europe, China, India, Africa, and the Other Asia/Pacific region (Table S9). To highlight the fuel-type information in the $\mathrm{CEDS}_{\mathrm{GBD}-\mathrm{MAPS}}$ inventory, Fig. S13 also illustrates global emissions of each compound as a function of fuel-group and sector, while Fig. S13-S20 illustrate the fuel-type contributions to emissions from the 11 world regions listed above. Figures S21 and S22 compare CEDS GBD- $_{\text {- }}$ MAPS and CEDS Hoesly $_{\text {emissions. Figures S23 and S24 provide an additional comparison of CEDS }}$ GBD-MAPS global sectoral emissions to sectoral emissions reported from the EDGAR v4.3.2 and GAINS (ECLIPSE v5a) inventories.

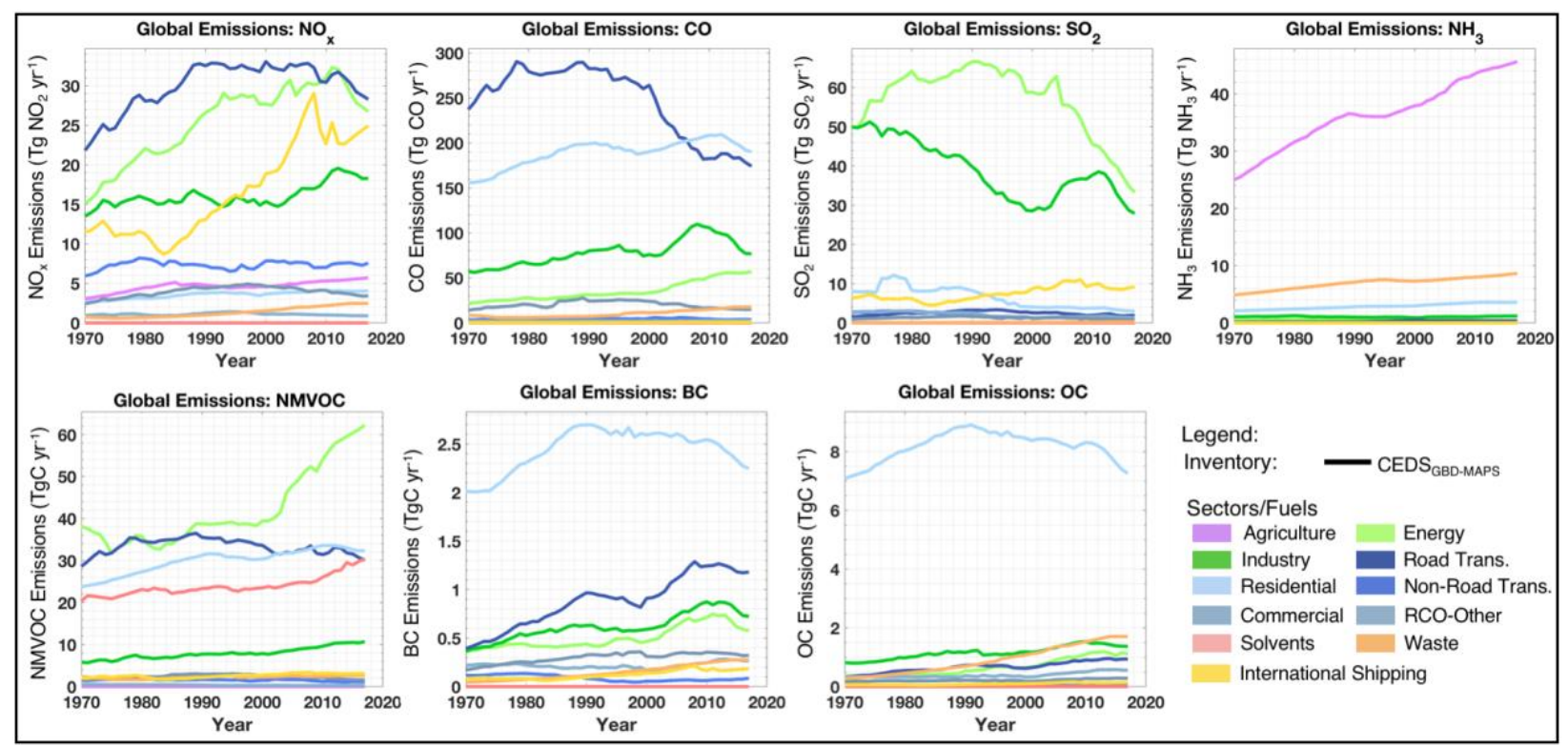

Figure S6. Time series of global emissions for each compound as a function of emission sector (all fuel types shown).

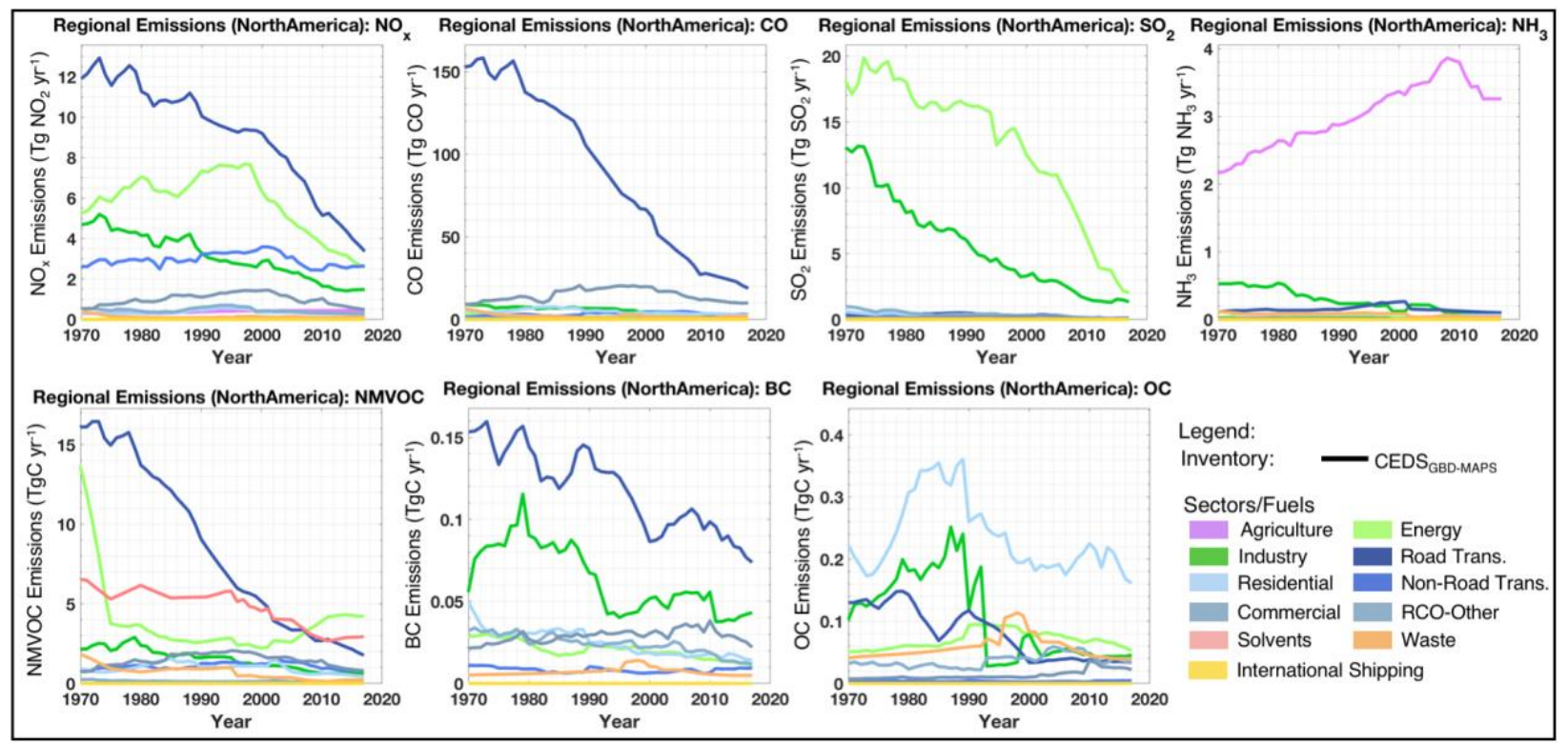

Figure S7. Time series of emissions in North America, as a function of emission sector (all fuel types shown). 

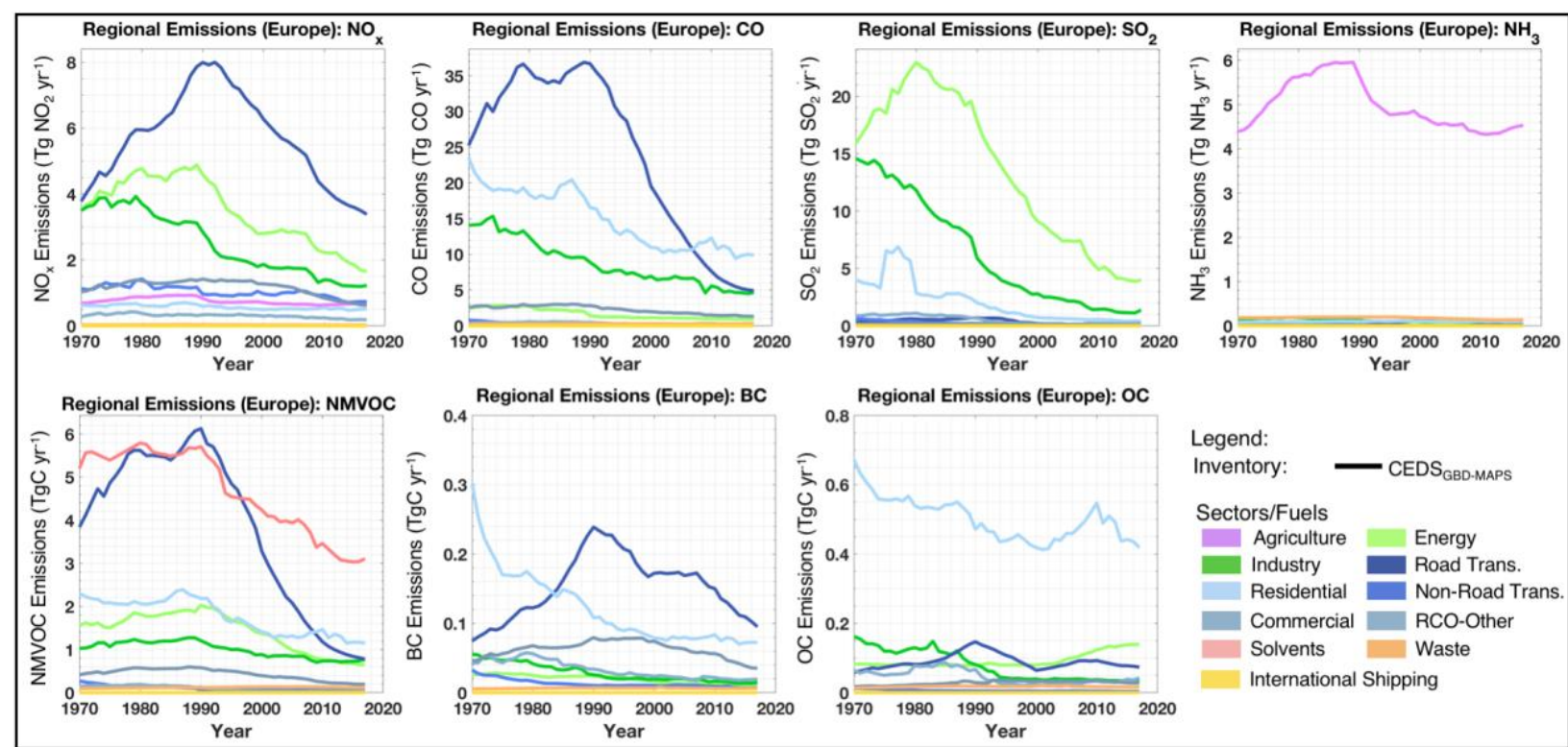

Figure S8. Time series of emissions in Europe, as a function of emission sector (all fuel types shown).
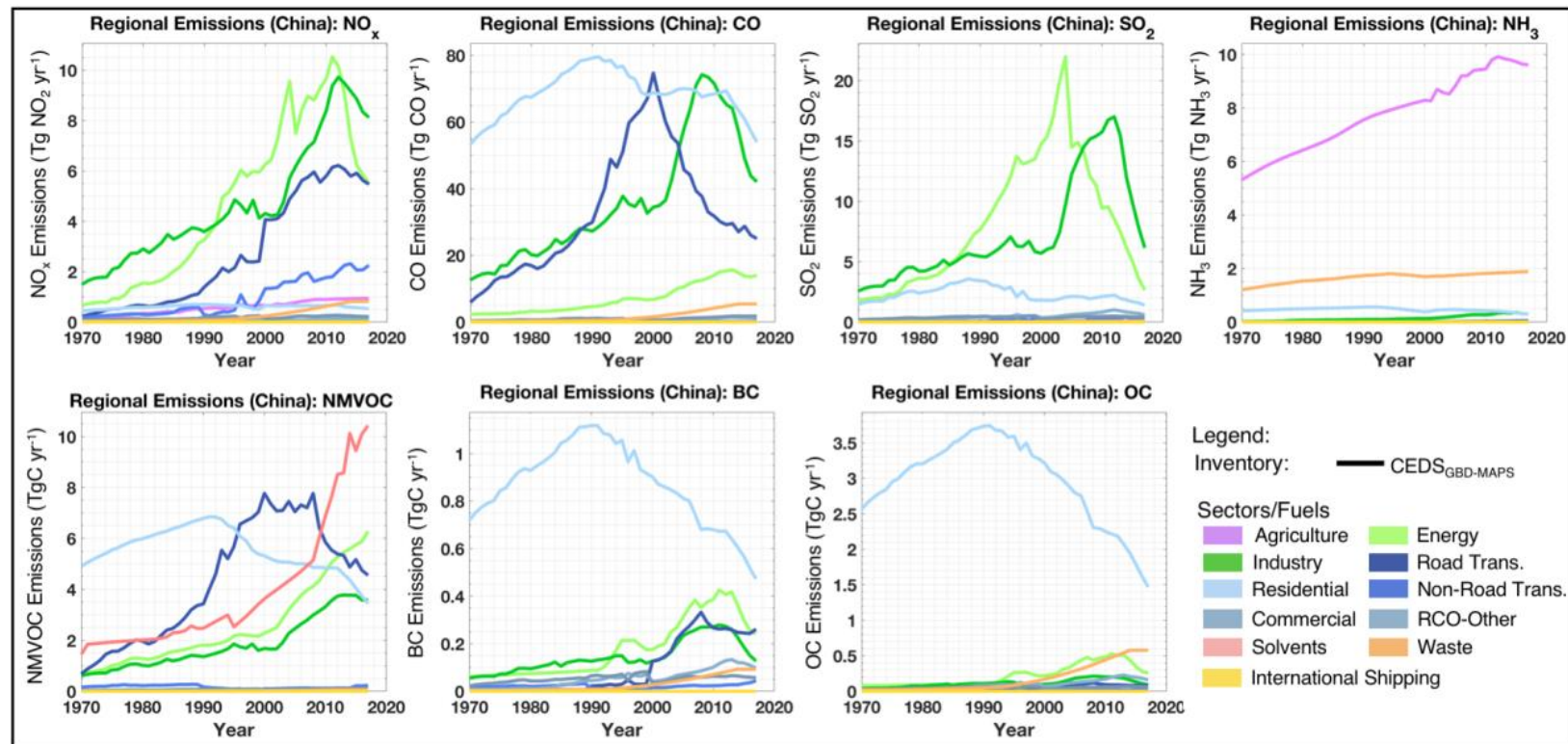

Figure S9. Time series of emissions in China, as a function of emission sector (all fuel types shown). 

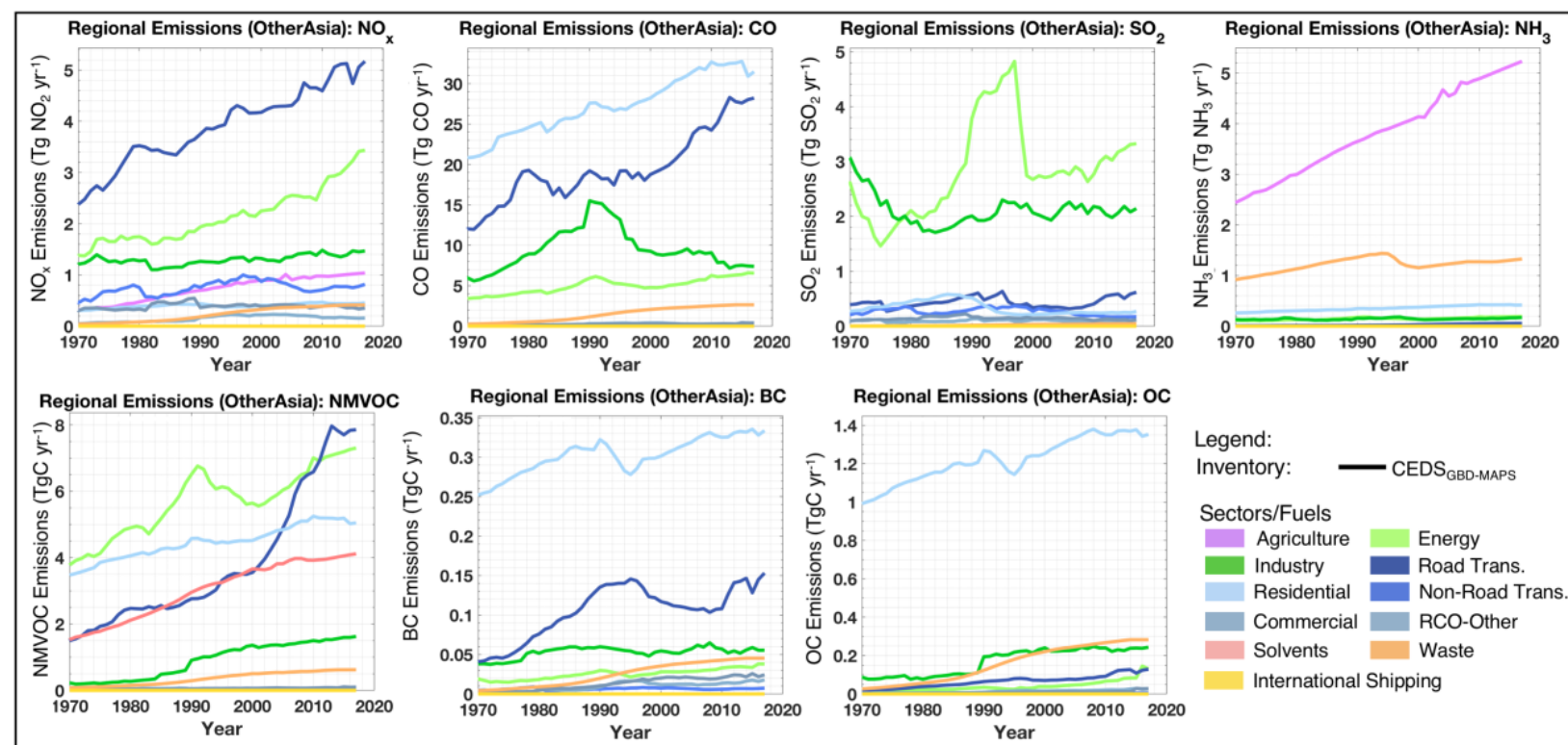

Legend:

Inventory: - CEDS $_{\text {GBD-MAPS }}$

Sectors/Fuels

- Agriculture Energy

Industry Road Trans.

Residential Non-Road Trans.

Commercial RCO-Other

Solvents Waste

International Shipping

Figure S10. Time series of emissions in the Other Asia/Pacific region (Table S9), as a function of emission sector (all fuel types shown).
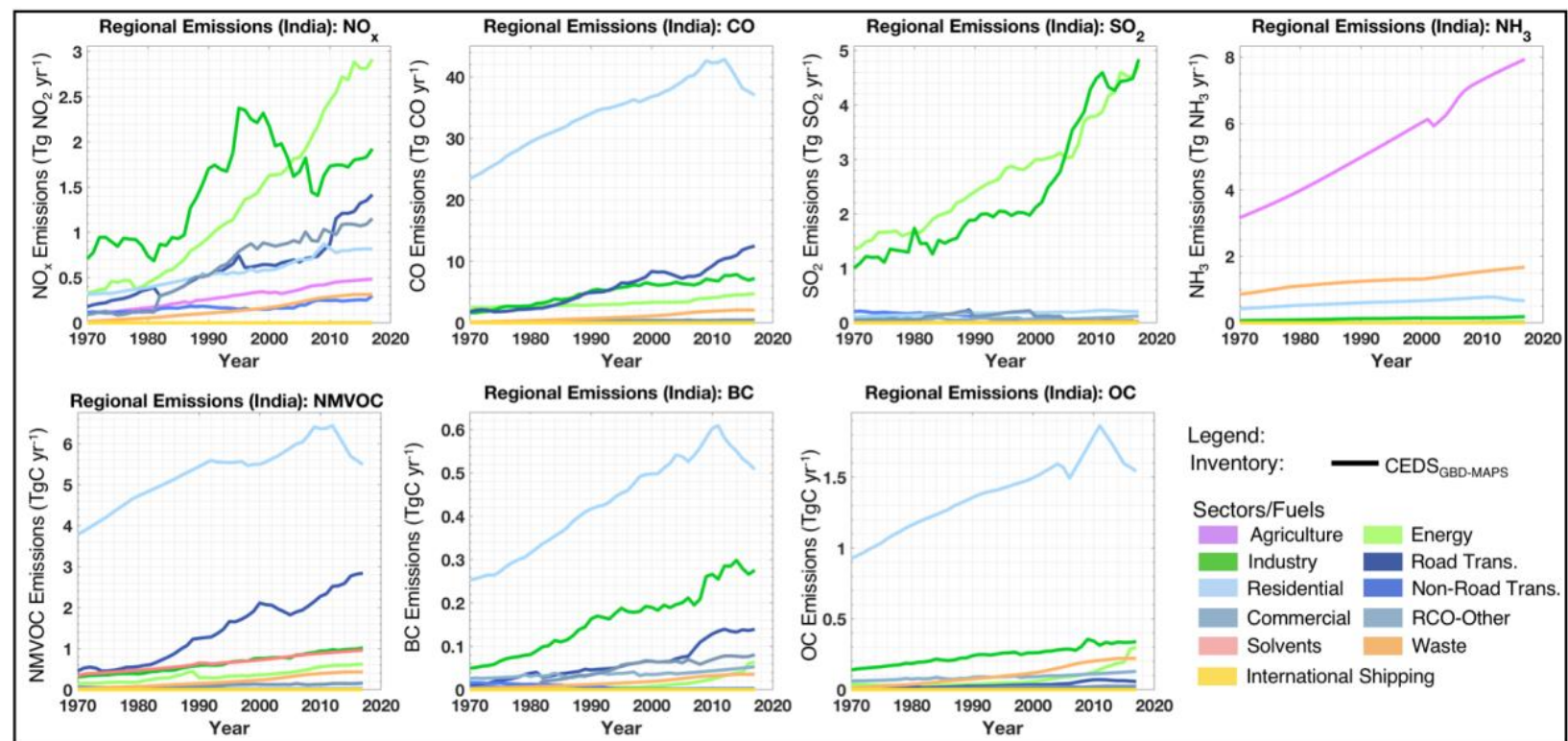

Figure S11. Time series of emissions in India, as a function of emission sector (all fuel types shown). 

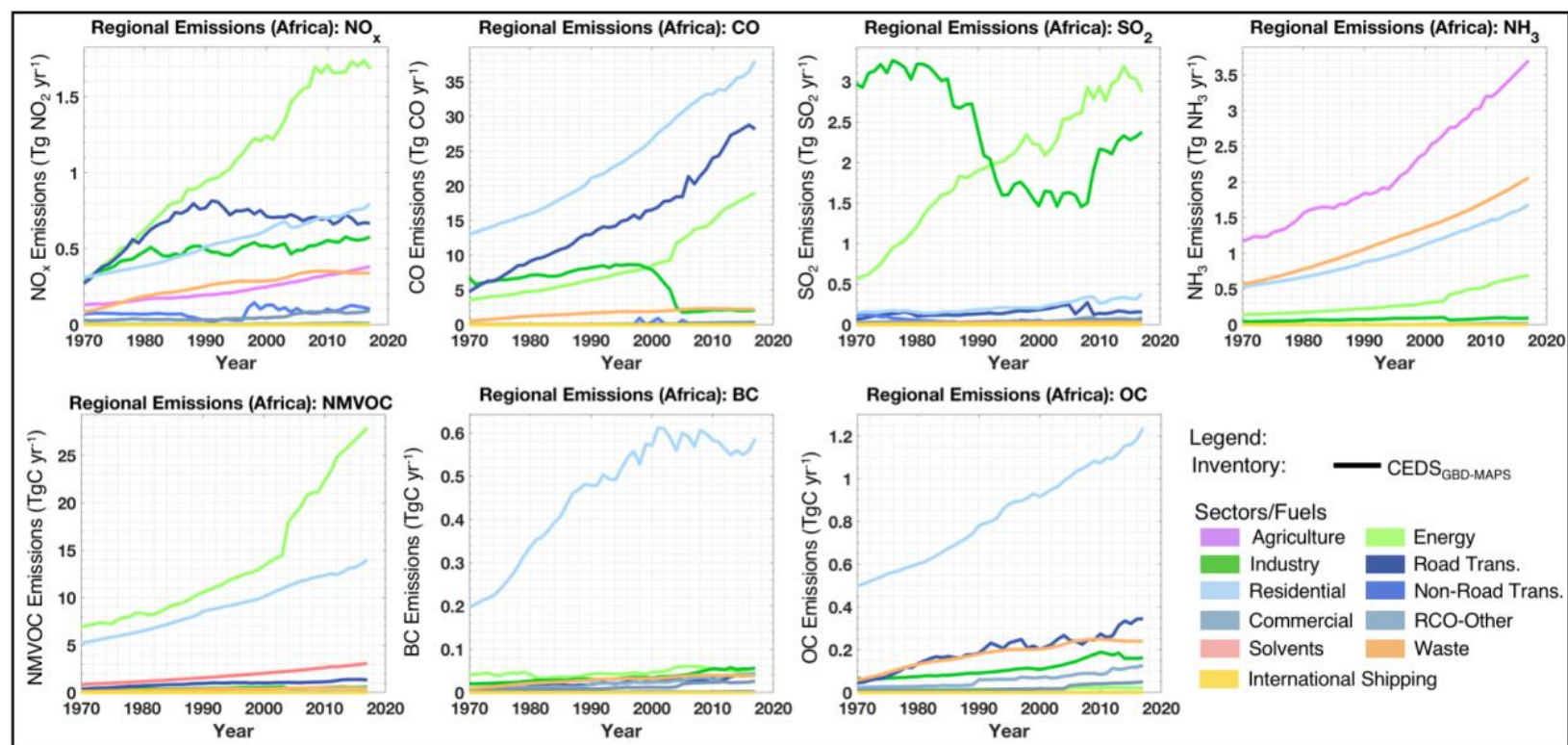

Figure S12. Time series of emissions in Africa, as a function of emission sector (all fuel types shown).
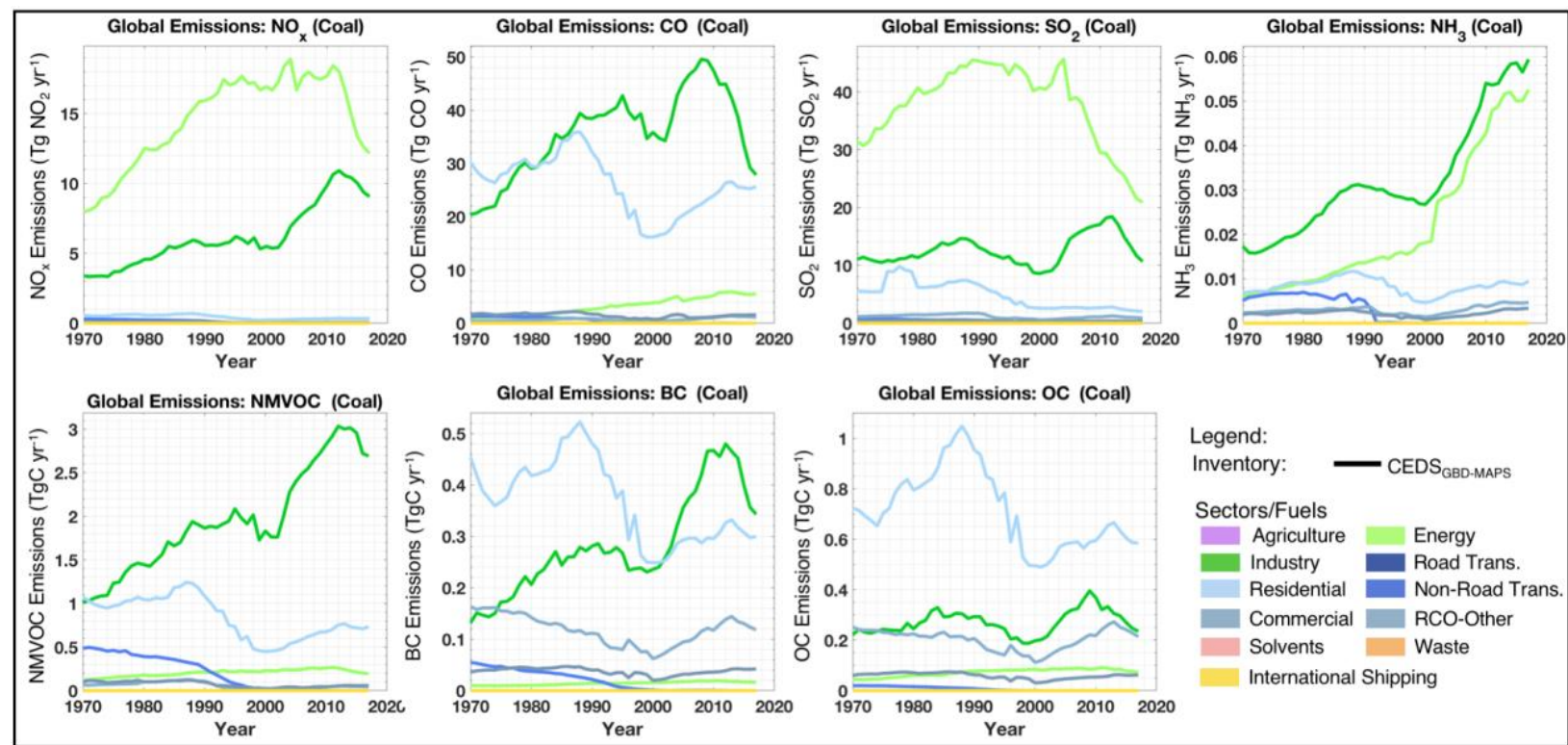

Figure S13. Time series of global sectoral emissions associated with coal combustion. 

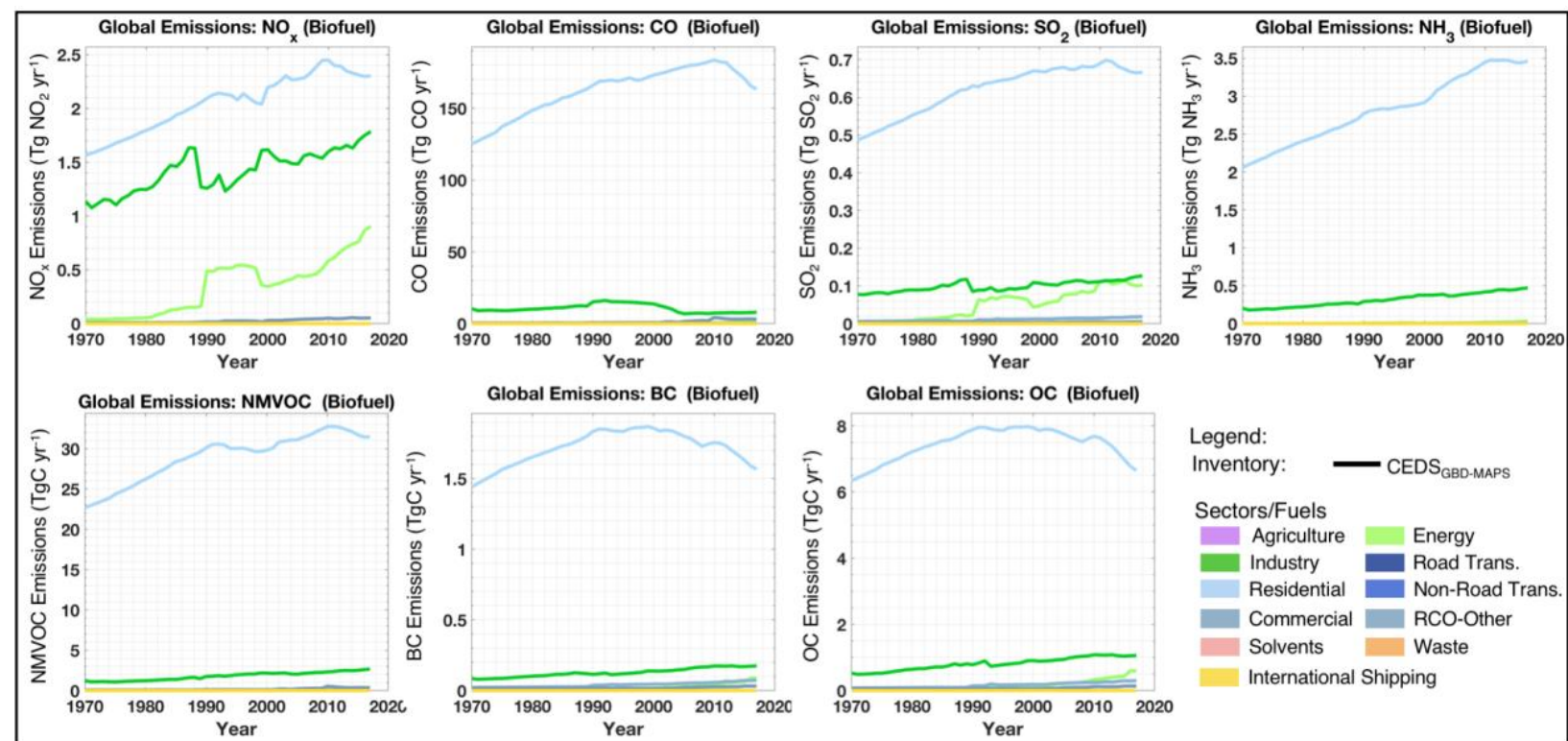

Figure S14. Time series of global sectoral emissions associated with solid biofuel combustion.
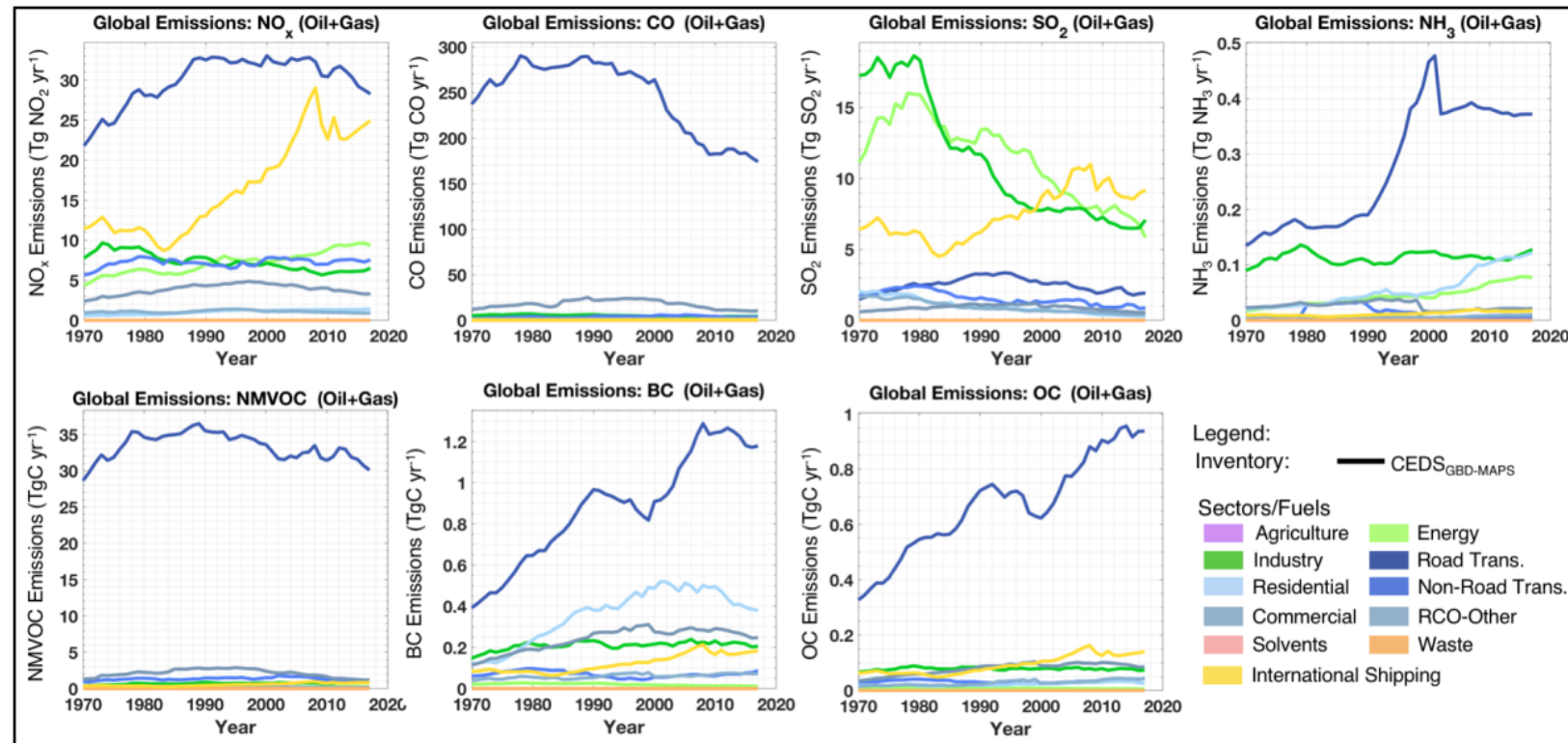

Global Emissions: OC (Oil+Gas)
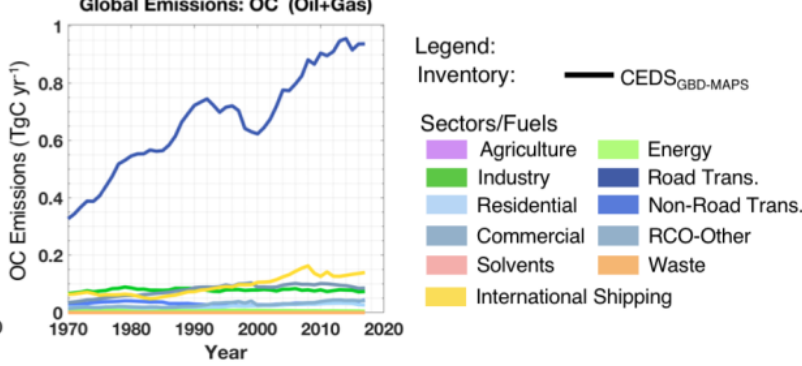

Figure S15. Timeseries of global sectoral emissions associated with the combustion of liquid oil and natural gas. 

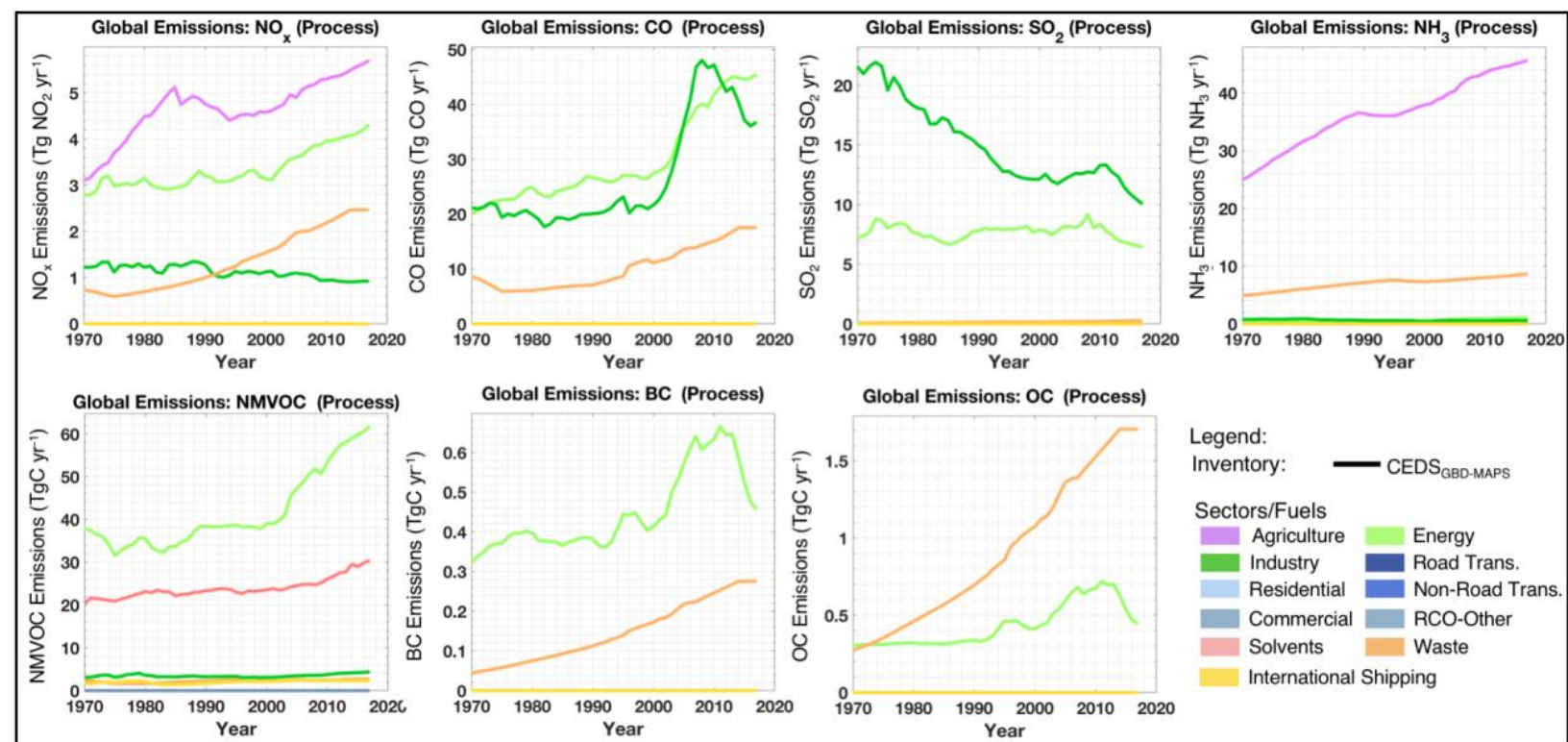

Figure S16. Timeseries of global sectoral emissions associated with CEDS process-level emission sources (Table 2)
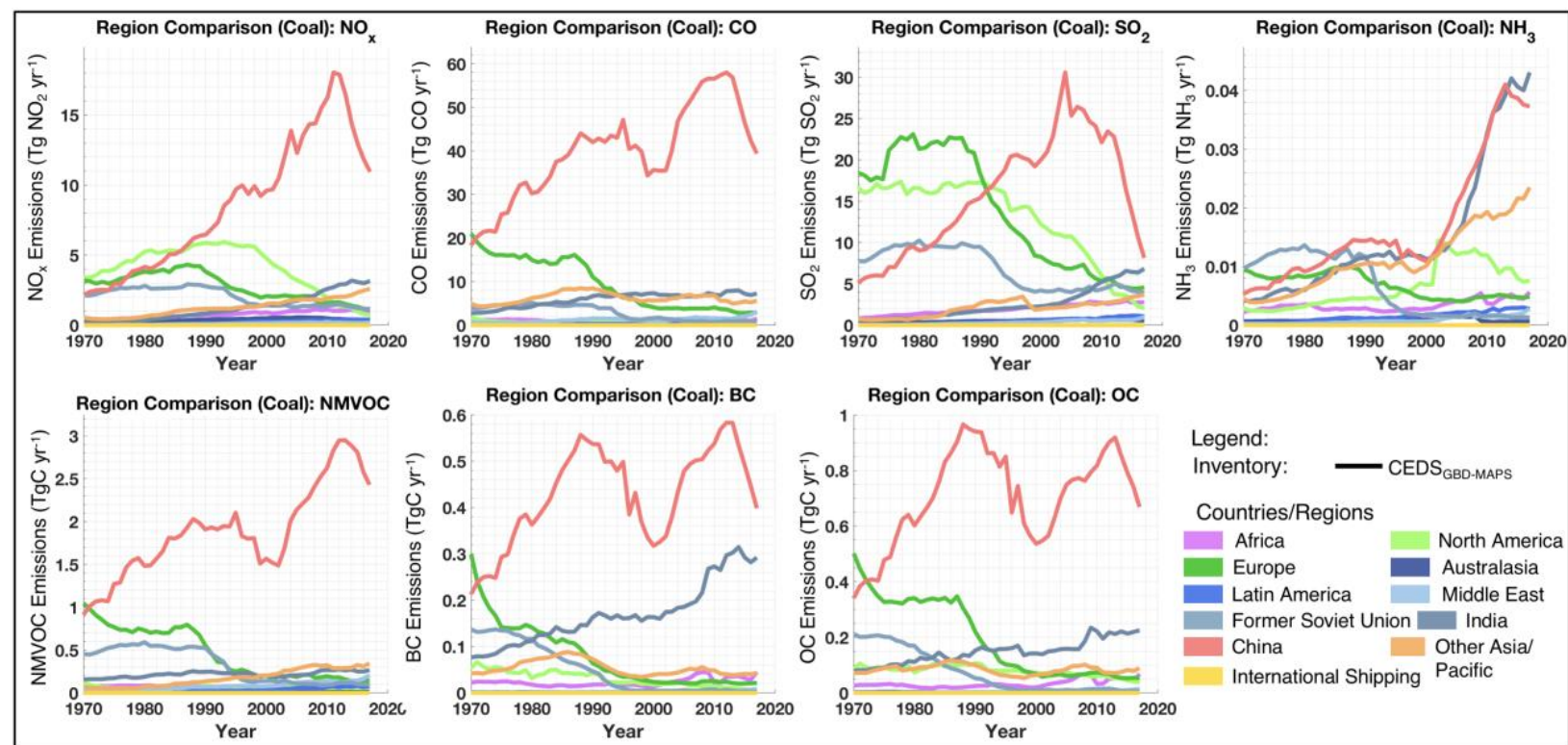

Figure S17. Timeseries of emissions associated with coal combustion, split into contributions from 11 world countries/regions (from coal combustion in all sectors). 

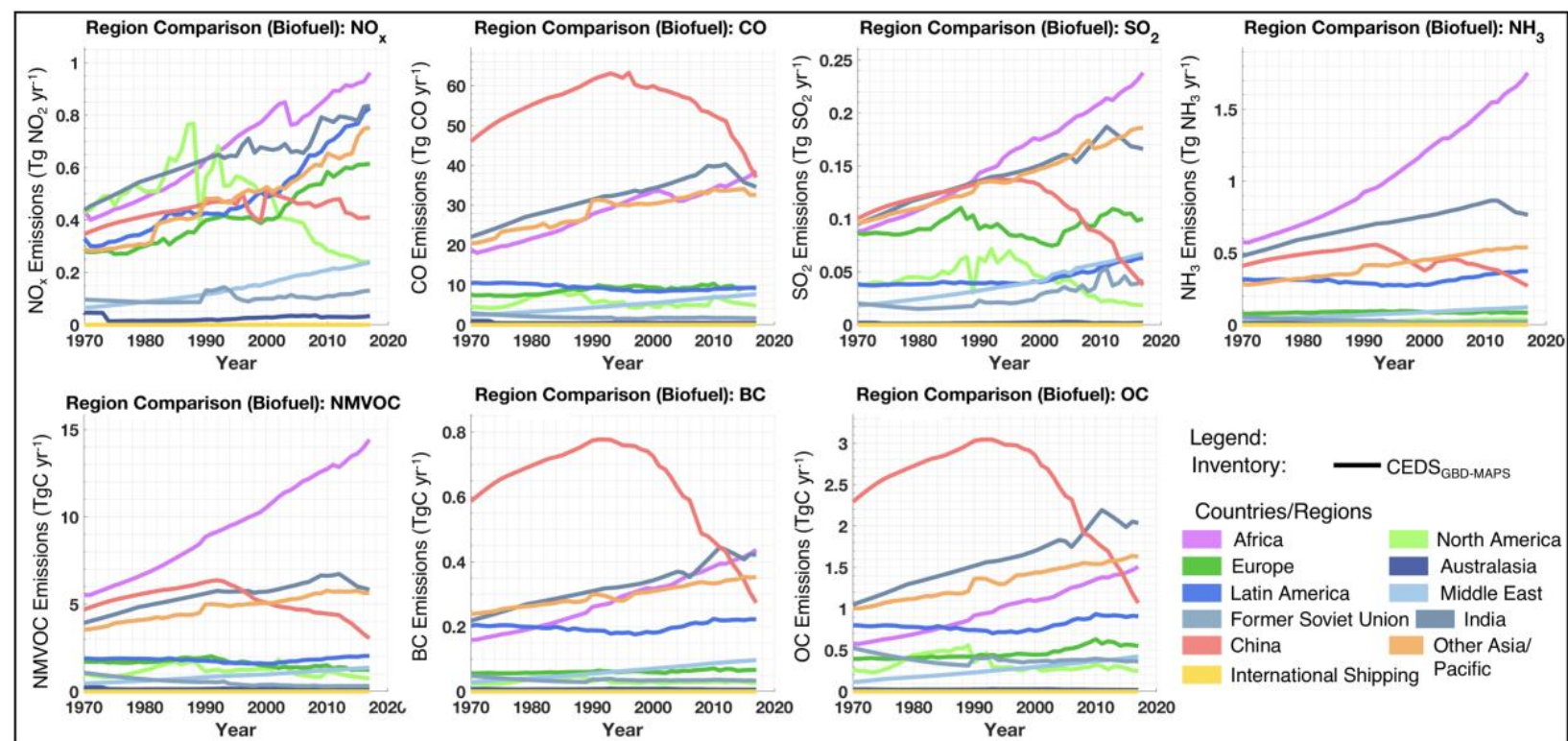

Figure S18. Timeseries of emissions associated with solid biofuel combustion, split into contributions from 11 world countries/regions (from biofuel combustion in all sectors).
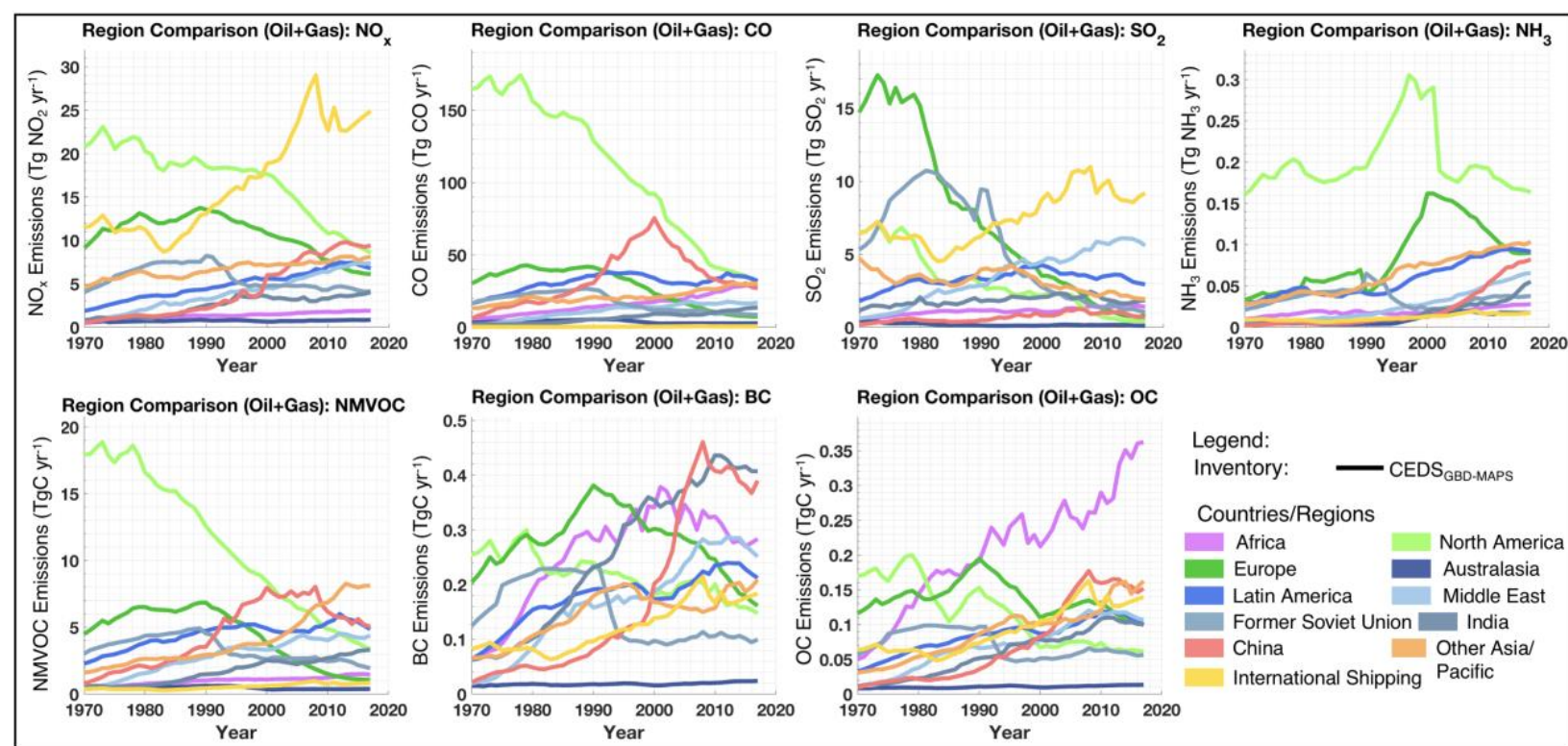

Figure S19. Timeseries of emissions associated with the combustion of liquid oil and natural gas, split into contributions from 11 world countries/regions. 


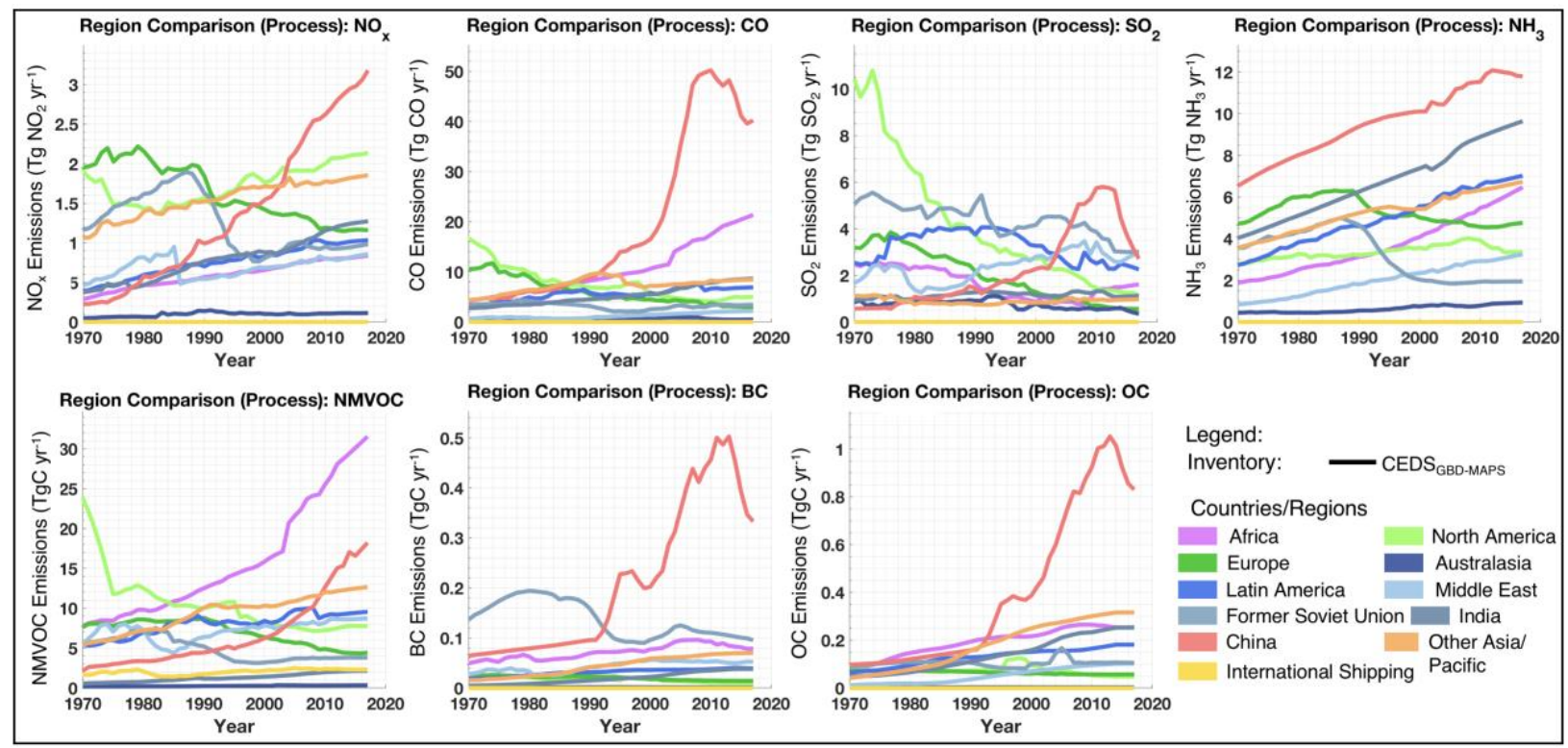

Figure S20. Timeseries of emissions from CEDS process-level sources (Table 2), split into contributions from 11 world countries/regions.
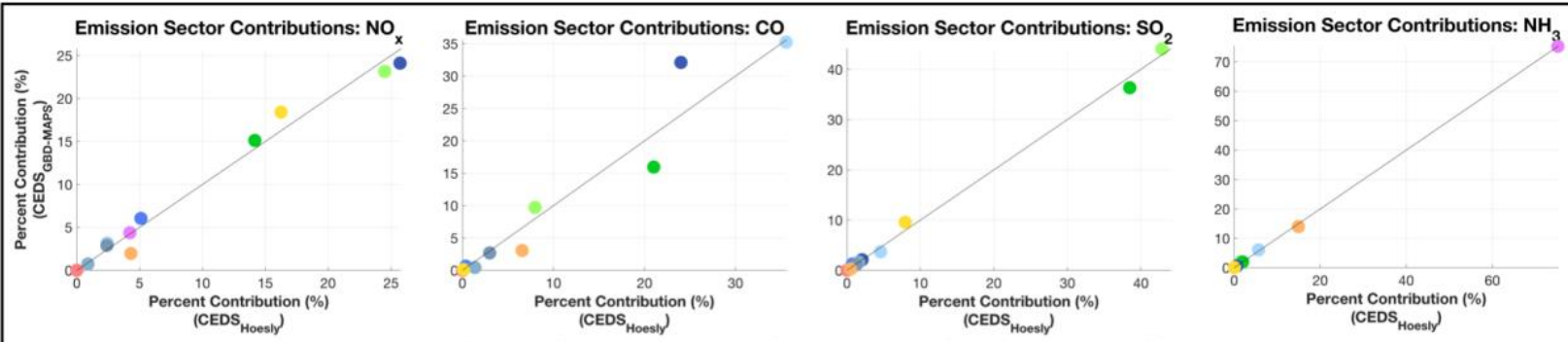

Emission Sector Contributions: NMVOC
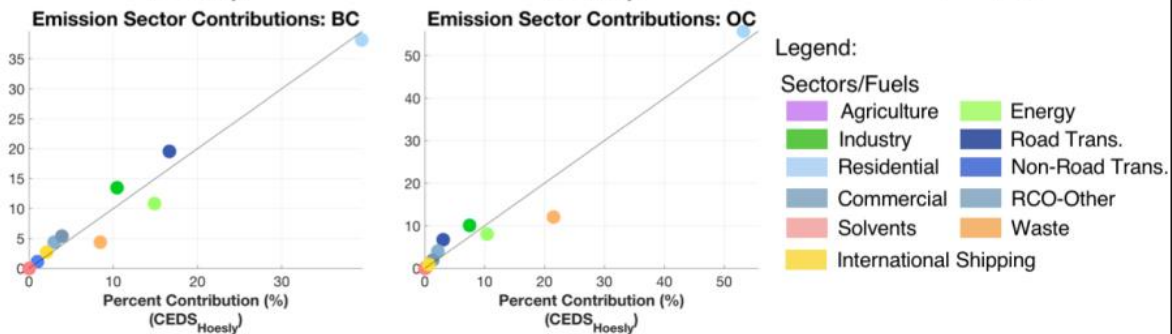

Legend:
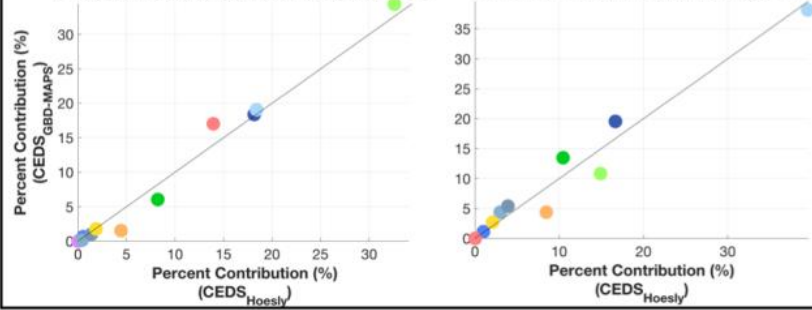

Figure S21. Comparison of CEDS sectoral fractional contributions in the CEDSGBD-MAPS ( $y$-axis) and CEDSHoesly (x-axis) inventories. Fractional contributions are calculated from global total emissions from all fuel types (= Sector X/ Total global emissions). Black line in the 1:1 line. Points are colored by sector. 


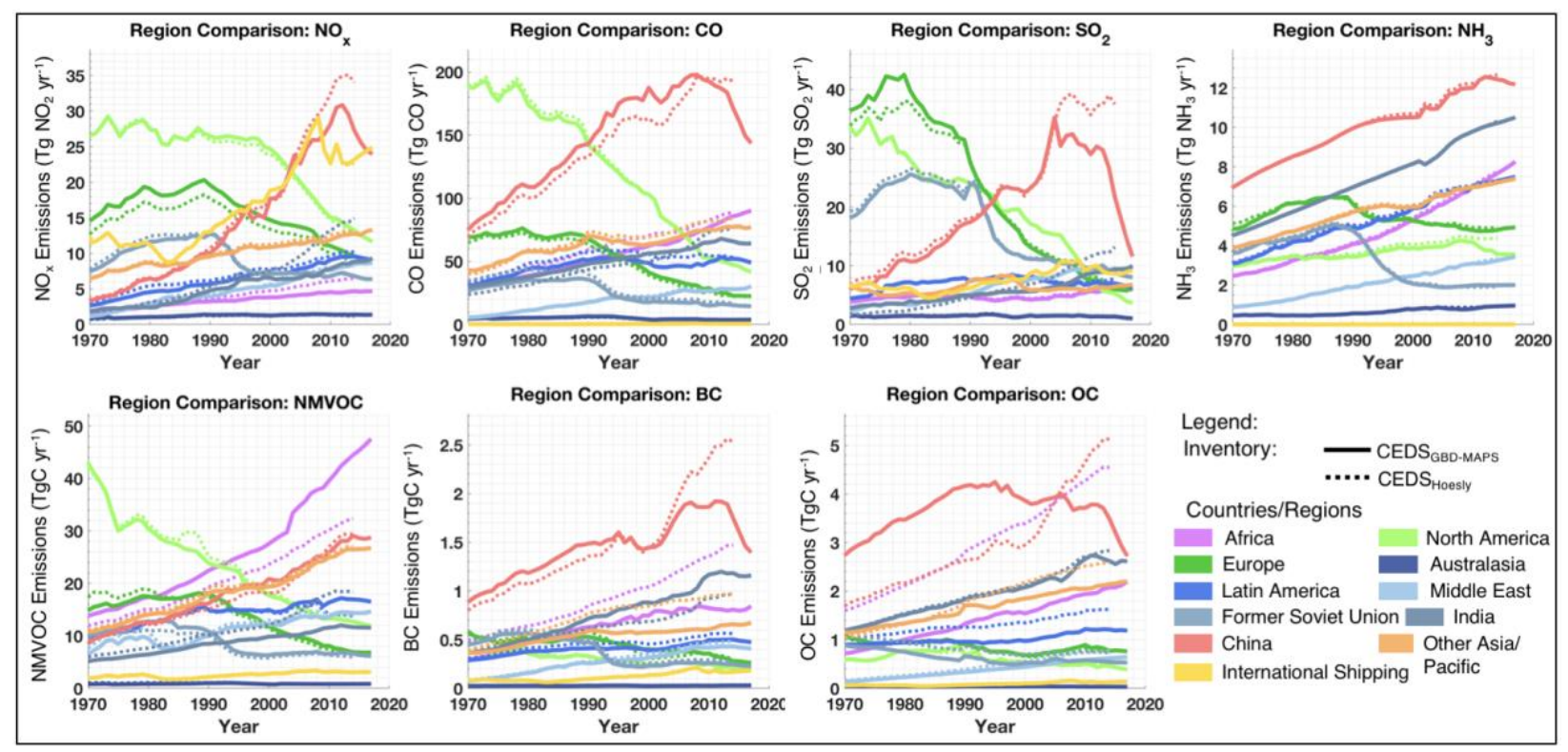

Figure S22. Comparison of CEDShoesly and CEDSGbD-MAPs emissions as a function of 11 world regions.

Table S10. Mapping between EDGAR v4.3.2, ECLIPSE v5a (GAINS), and CEDS

\begin{tabular}{|c|c|c|c|}
\hline $\begin{array}{l}\text { Aggregate Figure } \\
\text { Sectors }\end{array}$ & $\begin{array}{l}\text { CEDS }_{\text {GBD-MAPS }} \\
\text { Final Sectors }\end{array}$ & EDGAR v4.3.2 Reported Sectors & $\begin{array}{l}\text { ECLIPSE v5a (gridded data) } \\
\text { sectors }\end{array}$ \\
\hline Agriculture & AGR & $\begin{array}{l}\text { 4A - Enteric fermentation } \\
\text { 4B - Manure management } \\
\text { 4C - Rice cultivation } \\
\text { 4D1/4D2/4D4 - Direct soil emissions }\end{array}$ & $\begin{array}{l}\text { Agriculture - livestock and arable } \\
\text { land operations (AGR) }\end{array}$ \\
\hline Energy & ENE & $\begin{array}{l}\text { 1A1a - Public electricity and heat production } \\
\text { 1A1bc/1A5 - Other energy industries } \\
\text { 1B1 - Fugitive solid fuels } \\
\text { 1B2 - Fugitive oil and gas } \\
\text { 7A - Fossil fuel fires }\end{array}$ & $\begin{array}{l}\text { Energy - power plants, energy } \\
\text { production/ conversion, fossil fuel } \\
\text { distribution (ENE) }\end{array}$ \\
\hline Industry & IND & $\begin{array}{l}\text { 1A2 - Manufacturing and Construction } \\
\text { 2A1 - Cement Production } \\
\text { 2A }- \text { Lime Production } \\
\text { 2A } 4 \text { - Soda Ash Production } \\
\text { 2A7 - Other mineral production } \\
\text { 2B - Other Chemical Production } \\
\text { 2C - Metal Production } \\
\text { 2D - Pulp/paper/food/drink Production }\end{array}$ & Industrial combustion (IND) \\
\hline $\begin{array}{l}\text { On-road }+ \\
\text { Non-Road Transportation }\end{array}$ & $\begin{array}{l}\text { ROAD } \\
\text { NRTR }\end{array}$ & $\begin{array}{l}\text { 1A3b-Road transportation } \\
\text { 1A3c-Rail transportation } \\
\text { 1A3d - Inland navigation } \\
\text { 1A3e-Other transportation }\end{array}$ & $\begin{array}{l}\text { Transport - on-road and non-road } \\
\text { (TRA) }\end{array}$ \\
\hline $\begin{array}{l}\text { Residential + } \\
\text { Commercial + } \\
\text { Other }\end{array}$ & $\begin{array}{l}\text { RCOR } \\
\text { RCOC } \\
\text { RCOO } \\
\end{array}$ & 1A4 - Residential and other sectors & $\begin{array}{l}\text { Residential and commercial } \\
\text { combustion (DOM) }\end{array}$ \\
\hline Solvent Use & SLV & $\begin{array}{l}\text { 3A - Solvent and other product use: paint } \\
\text { 3B - Solvent and other product use: degrease } \\
\text { 3C - Solvent and other product use: chemicals } \\
\text { 3D - Solvent and other product use: other }\end{array}$ & Solvent use (SLV) \\
\hline Waste & WST & $\begin{array}{l}\text { 6A - Solid waste disposal on land } \\
6 \mathrm{~B}-\text { Wastewater handling } \\
6 \mathrm{C}-\text { Waste incineration } \\
\text { 6D - Other waste handling }\end{array}$ & $\begin{array}{l}\text { Waste disposal, including burning } \\
\text { (WST) }\end{array}$ \\
\hline International Shipping & SHP & 1C2 - International shipping & International shipping (SHP) \\
\hline
\end{tabular}



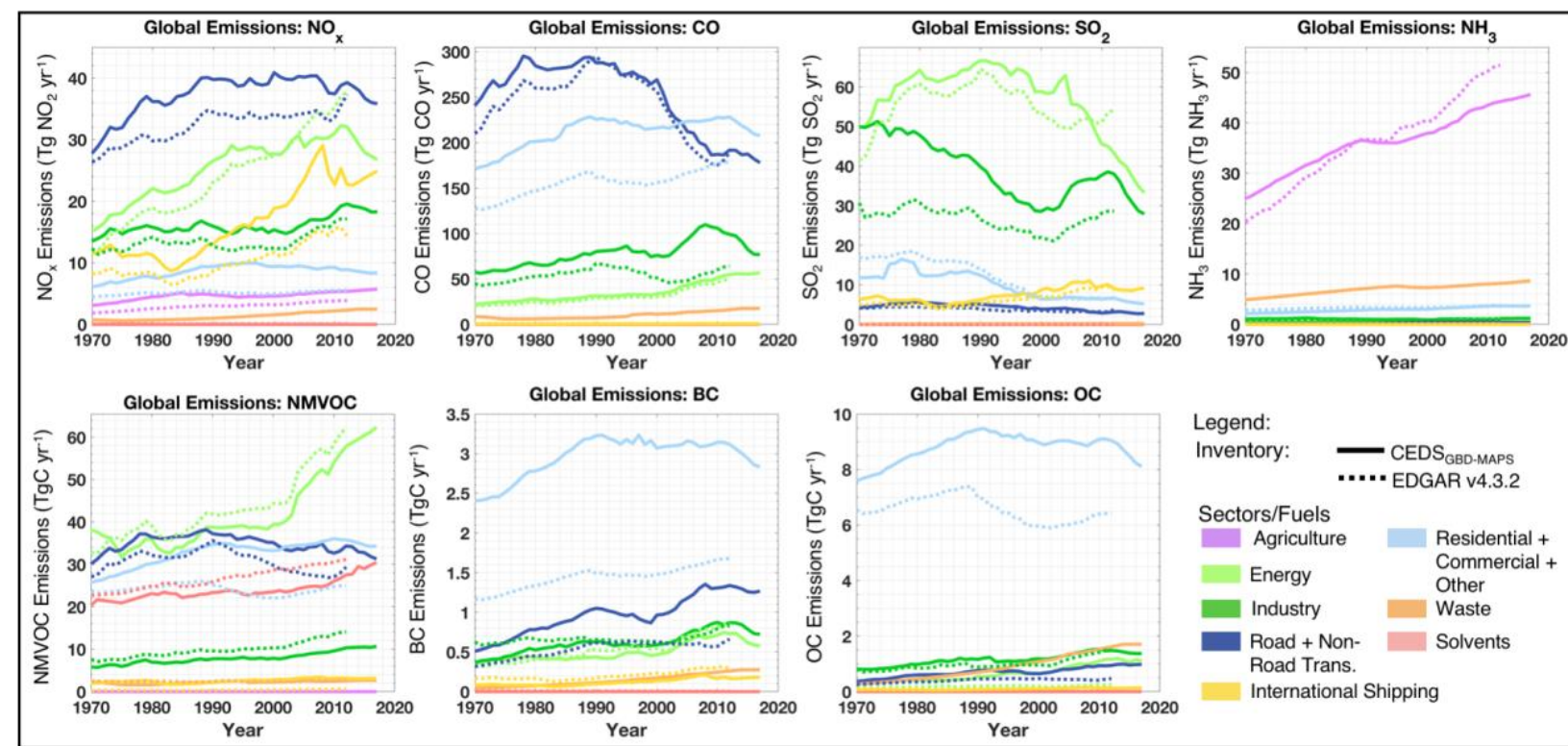

Figure S23. Comparison of sectoral global emissions in CEDS ${ }_{\text {GBD-MAPS }}$ and EDGARv4.3.2 inventories. CEDS ${ }_{\text {GBD-MAPS }}$ emissions are shown by solid lines, EDGARv4.3.2 data are shown by dashed lines. Sectoral mappings are in Table S10.
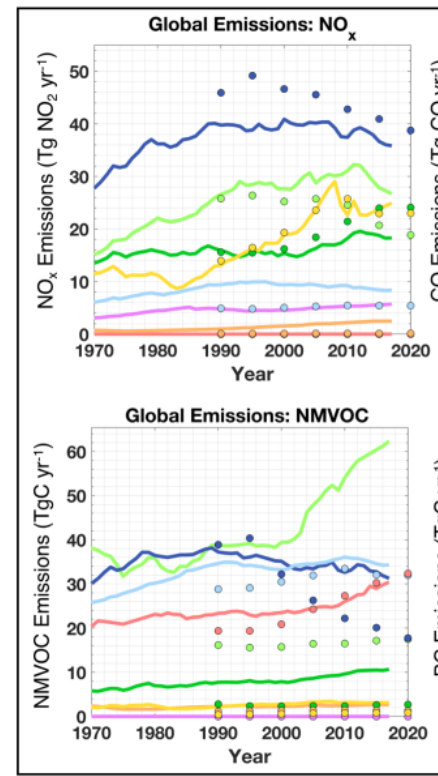

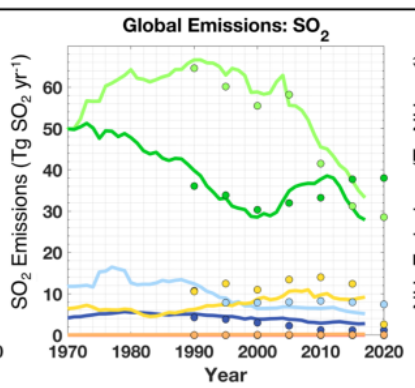

Global Emissions: OC
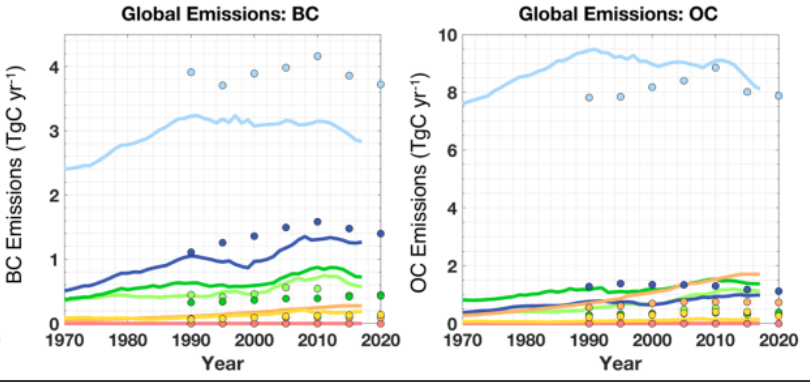

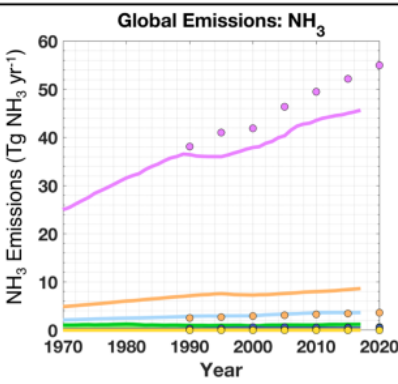

Legend:

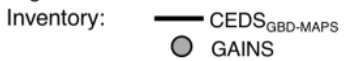

Sectors/Fuels

Agriculture Residential +

Energy Commercial

Industry $\quad$ Other

Road + Non- Solvents Road Trans.

International Shipping

Figure S24. Comparison of sectoral global emissions in CEDSGBD-MAPS and GAINS inventories. CEDSGBD-MAPS emissions are shown by solid lines, GAINS data are shown by dashed lines. Sectoral mappings are in Table S10.

\section{Section S4. Known Inventory Issues}

This list is up to date as the submission of the ESSD discussion paper describing the CEDS GBD-MAPs $_{\text {system and the }}$ associated data. These issues are in addition to known issues already recognized from the core CEDSv2019-12-23 system (https://github.com/JGCRI/CEDS/issues). New issues after this point will be listed using the issues tracking system on the GitHub repository for both the core CEDS and $\operatorname{CEDS}_{\mathrm{GBD}-M A P S}$ systems at: https://github.com/JGCRI/CEDS/issues and https://github.com/emcduffie/CEDS/issues. 
- $\mathrm{SO}_{2}$ and $\mathrm{NO}_{\mathrm{x}}$ emissions from the energy sector in China are too large between 1978 and 2004. This issue results from an issue in the underlying IEA energy data, which manifests in the spikes in $\mathrm{SO}_{2}$ and $\mathrm{NO}_{\mathrm{x}}$ energy emissions in 2004 that are visible in Fig. S9. This issue may result in up to a $10 \mathrm{Tg}$ overprediction in $\mathrm{SO}_{2}$ emissions from the energy sector in 2004, which decrease to a maximum possible overprediction of $0.3 \mathrm{Tg}$ by 1978. For $\mathrm{NO}_{\mathrm{x}}$ emissions, the maximum overprediction is $4 \mathrm{Tg}$ in 2004, which decreases to $0.1 \mathrm{Tg}$ by 1978 .

- As discussed in Sect. S2.3, industrial emissions of $\mathrm{NO}_{\mathrm{x}}$ in India may be overpredicted by up to $1 \mathrm{Tg}$ between 1987 and 2014. This results from the potential misallocation of the SMoG-India 'Informal Industry' sector to the $\mathrm{CEDS}_{\mathrm{GBD}-\mathrm{MAPS}}$ 1A2c_ind-Comb-Food-tobacco sector, rather than the 1A2g-Comb-Ind-other sector.

- Industry emissions of $\mathrm{NO}_{\mathrm{x}}$ and $\mathrm{SO}_{2}$ in China may not account for emissions from metal smelting due to uncertainties in the MEIC sectoral scaling mapping files for industry sector emissions.

- Residential emissions of $\mathrm{SO}_{2}$ from the combustion of coal may be over-predicted by up to $4 \mathrm{Tg}$ between 1972 -1980 (Fig. S13). This sudden increase in emissions from this sector is associated with the CEDS ${ }_{\text {GBD-MAPS }}$ procedures and not the underlying IEA energy data.

\section{References}

Boden, T. A., Marland, G., and Andres, R. J.: Global, Regional, and National Fossil-Fuel $\mathrm{CO}_{2}$ Emissions, Carbon Dioxide Information Analysis Center, U.S. Department of Energy, Oak Ridge, Tenn., U.S.A., 2016.

Boden, T. A., Marland, G., and Andres, R. J.: Global, Regional, and National Fossil-Fuel $\mathrm{CO}_{2}$ Emissions, Carbon Dioxide Information Analysis Center, U.S. Department of Energy, Oak Ridge, Tenn., U.S.A., doi: 10.3334/CDIAC/00001_V2017, 2017.

Bond, T. C., Bhardwaj, E., Dong, R., Jogani, R., Jung, S., Roden, C., Streets, D. G., and Trautmann, N. M.: Historical emissions of black and organic carbon aerosol from energy-related combustion, 1850-2000, Global Biogeochemical Cycles, 21, 10.1029/2006GB002840, 2007.

BP: BP Statistical Review of World Energy, bp.com/statisticalreview (last access: 15 January 2018), 2015.

BP: Statistical Review of World Energy: 2019, https://www.bp.com/content/dam/bp/businesssites/en/global/corporate/pdfs/energy-economics/statistical-review/bp-stats-review-2019-full-report.pdf (last access: January 23, 2020), 2019.

Commoner, B., Bartlett, P. W., Eisl, H., and Couchot, K.: Air Transport of Dioxin from North American Sources to Ecologically Vulnerable Receptors in Nunavut, Arctic Canada: Final Report to the North American Commission for Environmental Cooperation., http://www3.cec.org/islandora/en/item/1596-long-range-air-transport-dioxin-fromnorth-american-sources-ecologically-vulnerable-en.pdf (last access: 25 April, 2020), 2000.

Crippa, M., Guizzardi, D., Muntean, M., Schaaf, E., Dentener, F., van Aardenne, J. A., Monni, S., Doering, U., Olivier, J. G. J., Pagliari, V., and Janssens-Maenhout, G.: Gridded emissions of air pollutants for the period 19702012 within EDGAR v4.3.2, Earth Syst. Sci. Data, 10, 1987-2013, 10.5194/essd-10-1987-2018, 2018.

Doxsey-Whitfield, E., MacManus, K., Adamo, S. B., Pistolesi, L., Squires, J., Borkovska, O., and Baptista, S. R.: Taking Advantage of the Improved Availability of Census Data: A First Look at the Gridded Population of the World, Version 4, Papers in Applied Geography, 1, 226-234, 10.1080/23754931.2015.1014272, 2015. 
EC-JRC: Emissions Database for Global Atmospheric Research (EDGAR), release EDGARv4.3.2 https://edgar.jrc.ec.europa.eu/overview.php?v=432_AP, https://data.europa.eu/doi/10.2904/JRC_DATASET_EDGAR, (last access: 12 August 2019), 2018.

EC-JRC/PBL: Emission Database for Global Atmospheric Research (EDGAR), release EDGAR v4.2 FT2012, http://edgar.jrc.ec.europa.eu (last access: 15 January 2018), 2012.

EC-JRC/PBL: Emission Database for Global Atmospheric Research (EDGAR), release version 4.3.1, http://edgar.jrc.ec.europa.eu/overview.php?v=431 (last access: 15 January 2018), 2016.

EIA: U.S. Energy Information Administration: Table 10.2a: Renewable Energy Cnsumption, Residential and Commercial Sectors, https://www.eia.gov/totalenergy/data/monthly/\#renewable (last access: 26 August 2019), 2019.

EMEP: Officially reported emission data to the European Monitoring and Evaluation Programme:

EMEP_NFR14_LEVEL1 data, https://www.ceip.at/ms/ceip_home1/ceip_home/webdab_emepdatabase/reported_emissiondata/(last access: 19 December 2019), 2019.

FAOSTAT: FAOSTAT-Forestry database, http://www.fao.org/forestry/statistics/84922/en/ (last access: 15 January 2018), 2015.

Hoesly, R., O'Rourke, P., Braun, C., Feng, L., Smith, S. J., Pitkanen, T., Siebert, J., Vu, L., Presley, M., Bolt, R., Goldstein, B., and Kholod, N.: CEDS: Community Emissions Data System (Version Dec-23-2019), http://doi.org/10.5281/zenodo.3592073 (last access: March 15, 2020), 2019.

Hoesly, R. M., Smith, S. J., Feng, L., Klimont, Z., Janssens-Maenhout, G., Pitkanen, T., Seibert, J. J., Vu, L., Andres, R. J., Bolt, R. M., Bond, T. C., Dawidowski, L., Kholod, N., Kurokawa, J. I., Li, M., Liu, L., Lu, Z., Moura, M. C. P., O'Rourke, P. R., and Zhang, Q.: Historical (1750-2014) anthropogenic emissions of reactive gases and aerosols from the Community Emissions Data System (CEDS), Geosci. Model Dev., 11, 369-408, 10.5194/gmd-11369-2018, 2018.

IEA: World Energy Statistics, http://www.iea.org/statistics/ (last access: 15 January 2018), 2015.

IEA: World Energy Statistics 2019 Edition, Database Documentation, http://wds.iea.org/wds/pdf/WORLDBES Documentation.pdf (last access: 17 September 2019), 2019.

Klein Goldewijk, K., Beusen, A., van Drecht, G., and de Vos, M.: The HYDE 3.1 spatially explicit database of human-induced global land-use change over the past 12,000 years, Global Ecology and Biogeography, 20, 73-86, 10.1111/j.1466-8238.2010.00587.x, 2011.

Klimont, Z., Kupiainen, K., Heyes, C., Purohit, P., Cofala, J., Rafaj, P., Borken-Kleefeld, J., and Schöpp, W.: Global anthropogenic emissions of particulate matter including black carbon, Atmos. Chem. Phys., 17, 8681-8723, 10.5194/acp-17-8681-2017, 2017.

Kurokawa, J., Ohara, T., Morikawa, T., Hanayama, S., Janssens-Maenhout, G., Fukui, T., Kawashima, K., and Akimoto, H.: Emissions of air pollutants and greenhouse gases over Asian regions during 2000-2008: Regional Emission inventory in ASia (REAS) version 2, Atmos. Chem. Phys., 13, 11019-11058, 10.5194/acp-13-11019-2013, 2013.

Marais, E. A., and Wiedinmyer, C.: Air Quality Impact of Diffuse and Inefficient Combustion Emissions in Africa (DICE-Africa), Environ. Sci. Technol., 50, 10739-10745, 10.1021/acs.est.6b02602, 2016.

Meidiana, C., and Gamse, T.: Development of Waste Management Practices in Indonesia, European Journal of Scientific Research, 40, 199-210, 2010. 
Nagpure, A. S., Ramaswami, A., and Russell, A.: Characterizing the Spatial and Temporal Patterns of Open Burning of Municipal Solid Waste (MSW) in Indian Cities, Environ. Sci. Technol., 49, 12904-12912,

10.1021/acs.est.5b03243, 2015.

NEI: 2011 National Emissions Inventory (NEI) Data, https://www.epa.gov/air-emissions-inventories/2011-nationalemissions-inventory-nei-data(last), 2013.

Reyna-Bensusan, N., Wilson, D. C., and Smith, S. R.: Uncontrolled burning of solid waste by households in Mexico is a significant contributor to climate change in the country, Environmental Research, 163, 280-288, https://doi.org/10.1016/j.envres.2018.01.042, 2018.

Sharma, G., Sinha, B., Pallavi, Hakkim, H., Chandra, B. P., Kumar, A., and Sinha, V.: Gridded Emissions of CO, $\mathrm{NOx}, \mathrm{SO} 2, \mathrm{CO} 2, \mathrm{NH} 3, \mathrm{HCl}, \mathrm{CH} 4, \mathrm{PM} 2.5, \mathrm{PM} 10, \mathrm{BC}$, and NMVOC from Open Municipal Waste Burning in India, Environ. Sci. Technol., 53, 4765-4774, 10.1021/acs.est.8b07076, 2019.

Stohl, A., Aamaas, B., Amann, M., Baker, L. H., Bellouin, N., Berntsen, T. K., Boucher, O., Cherian, R., Collins, W., Daskalakis, N., Dusinska, M., Eckhardt, S., Fuglestvedt, J. S., Harju, M., Heyes, C., Hodnebrog, Ø., Hao, J., Im, U., Kanakidou, M., Klimont, Z., Kupiainen, K., Law, K. S., Lund, M. T., Maas, R., MacIntosh, C. R., Myhre, G., Myriokefalitakis, S., Olivié, D., Quaas, J., Quennehen, B., Raut, J. C., Rumbold, S. T., Samset, B. H., Schulz, M., Seland, Ø., Shine, K. P., Skeie, R. B., Wang, S., Yttri, K. E., and Zhu, T.: Evaluating the climate and air quality impacts of short-lived pollutants, Atmos. Chem. Phys., 15, 10529-10566, 10.5194/acp-15-10529-2015, 2015.

The World Bank: World Development Indicators, databank.worldbank.org/data/download/WDI_excel.zip (last access: 15 January 2018), 2016.

UN: World Urbanization Prospects: The 2014 Revision, https://esa.un.org/unpd/wup/CD-

ROM/WUP2014_XLS_CD_FILES/WUP2014-F01-Total_Urban_Rural.xls (last access: 15 January 2018), 2014.

UN: UN World Population Prospects: The 2015 Revision, http://esa.un.org/unpd/wpp/DVD/ (last access: 15 January 2018), 2015.

UN: World urbanization prospects: The 2018 revision, annual percentage of population at mid-year residing in urban areas by region, subregion, country and area, 1950-2050, https://population.un.org/wup/Download/(last access: 24 July 2019), 2018.

UN: World Population Prospects 2019: Total population (both sexes combined) by region, subregion and country, annually for 1950 to 2100, https://esa.un.org/unpd/wpp/Download/Standard/Population/(last), 2019.

US EPA: An inventory of sources and environmental releases of dioxin-like compounds in the U.S. for the years 1987, 1995, and 2000, U.S. Environmental Protection Agency, Washington DC, EPA/600/P-03/002F, 2006.

Venkataraman, C., Brauer, M., Tibrewal, K., Sadavarte, P., Ma, Q., Cohen, A., Chaliyakunnel, S., Frostad, J., Klimont, Z., Martin, R. V., Millet, D. B., Philip, S., Walker, K., and Wang, S.: Source influence on emission pathways and ambient PM2.5 pollution over India (2015-2050), Atmos. Chem. Phys., 18, 8017-8039, 10.5194/acp18-8017-2018, 2018.

Wiedinmyer, C., Yokelson, R. J., and Gullett, B. K.: Global Emissions of Trace Gases, Particulate Matter, and Hazardous Air Pollutants from Open Burning of Domestic Waste, Environ. Sci. Technol., 48, 9523-9530, 10.1021/es502250z, 2014.

Zheng, B., Tong, D., Li, M., Liu, F., Hong, C., Geng, G., Li, H., Li, X., Peng, L., Qi, J., Yan, L., Zhang, Y., Zhao, H., Zheng, Y., He, K., and Zhang, Q.: Trends in China's anthropogenic emissions since 2010 as the consequence of clean air actions, Atmos. Chem. Phys., 18, 14095-14111, 10.5194/acp-18-14095-2018, 2018. 